\title{
Normal Vibrations of Crystalline Polyglycine I
}

\author{
YASUAKI ABE and S. KRIMM,* Harrison M. Randall \\ Laboratory of Physics and Macromolecular Research Center, \\ University of Michigan, Ann Arbor, Michigan 48104
}

\begin{abstract}
Synopsis
A valence force field has been refined for crystalline polyglycine I using its known antiparallel chain pleated-sheet structure and without replacing the $\mathrm{CH}_{2}$ group by a point mass. Polyglycine I and four of its isotopic derivatives were used in the refinement. The calculated frequencies are in good agreement with the observed, except for the amide I modes. It is shown that this is a consequence of the fact that no reasonable force field predicts a large $D_{10}$ term of the Miyazawa perturbation treatment. The amide I splittings can, however, be satisfactorily accounted for by introducing a direct interaction force constant between adjacent $\mathrm{C}=\mathrm{O}$ groups in neighboring chains. This can reasonably arise from transition dipole coupling and corresponds to the heretofore neglected $D_{11}$ term.
\end{abstract}

\section{INTRODUCTION}

There have been many studies of the vibrational spectra of polyglycine, $\left(\mathrm{NHCH}_{2} \mathrm{CO}\right)_{n}$, the simplest member of the polypeptides, $+\mathrm{NHCH}-$ $\mathrm{RCO}{ }_{n}$, and of the polyamides $\left(\mathrm{NH}\left[\mathrm{CH}_{2}\right]_{m} \mathrm{CO}+_{n}\right.$ as well. The existence of two rotational-isomeric structures in the crystalline state was first suggested by Elliott and Malcolm from their infrared study. ${ }^{1}$ They named one form, which is obtained by casting from haloacetic acid solutions, polyglycine I (PG I) and the other, obtained by precipitation from an aqueous solution saturated with $\mathrm{LiBr}$, polyglycine II (PG II). The dichroism of the infrared bands of $P G I$, of which oriented samples are readily obtainable, was also measured by them. The far infrared region was studied by Miyazawa, ${ }^{2}$ who found large spectral differences between PG I and PG II. The most comprehensive infrared data on various isotopic molecules such as $-\mathrm{NHCH}_{2} \mathrm{CO}-,-\mathrm{N}^{15} \mathrm{HCH}_{2} \mathrm{CO}-,-\mathrm{NDCH}_{2} \mathrm{CO}-,-\mathrm{NHCD}_{2} \mathrm{CO}-$, and $-\mathrm{NDCD}_{2} \mathrm{CO}$ - were reported by Suzuki et al. ${ }^{3}$ Krimm and Kuroiwa analyzed low-temperature infrared spectra in relation to $\mathrm{N}-\mathrm{H}---\mathrm{O}=\mathrm{C}^{\prime}$ and $\mathrm{C}-\mathrm{H}--\mathrm{O}=\mathrm{C}^{\prime}$ hydrogen bonding. ${ }^{4}$ Raman data were reported recently by Smith et al. ${ }^{5}$ and by Small et al. ${ }^{6}$ Inelastic neutron scattering has been measured by Gupta et al. ${ }^{7,8}$ Infrared and Raman studies on oligomers and model compounds have been undertaken by several workers. ${ }^{5,9-11}$

* To whom correspondence should be addressed.

(C) 1972 by John Wiley \& Sons, Inc. 
Theoretical calculations of normal vibrations of polyglycines have also been carried out. However, most of these calculations are incomplete, in the sense that they were done on only one or two isotopic molecules and/or approximate structures. In addition, limited Urey-Bradley force fields were employed in the calculations. When compared with the abundance of experimental data mentioned above, a more refined calculation is clearly justifiable. As an extension of the recent study on the valence force field of the amide group, ${ }^{12,13}$ we have recalculated the normal vibrations of various isotopic molecules of crystalline PG I and of the PG II single chain, and have determined their valence force fields using the actual structures. The results on PG I are reported here and those on PG II in the following paper.

The normal vibrations of the PG I single chain were first treated by Fukushima et al. ${ }^{14,15}$ and then by Gupta et al. ${ }^{7}$ Fukushima and Miyazawa also treated the PG I crystal consisting of antiparallel chains. ${ }^{15,16}$ In all of these calculations the $\mathrm{CH}_{2}$ group was approximated by a single mass and the chain conformation was assumed to be planar. The present calculations were done on the actual conformation determined by $\mathrm{X}$-ray diffraction studies, and without replacing the $\mathrm{CH}_{2}$ group by a single mass.

\section{EXPERIMENTAL}

Far infrared spectra of $P G I$ in the $500-200 \mathrm{~cm}^{-1}$ region were obtained using Beckman IR 12 and Perkin-Elmer 180 spectrometers. The sample, from Sigma Chemical Company (molecular weight $\cong 6,000$ ), was purified by precipitating from a $1 \%$ solution of saturared aqueous $\mathrm{LiBr}$. It was then dissolved in dichloroacetic acid or trifluoroacetic acid and cast on polyethylene film. The film was folded over and pressed under ca 18,000 psi. Three bands were found at 321 (very weak), 270 (broad and weak), and at $217 \mathrm{~cm}^{-1}$ (medium). The band at $413 \mathrm{~cm}^{-1}$ reported by Gupta et al. ${ }^{7}$ was found in the unpurified sample, but disappeared upon purification.

\section{CALCULATION OF NORMAL VIBRATIONS}

The following normal coordinate treatment was carried out using the GF-matrix method ${ }^{17}$ modified for crystals and polymeric chains. ${ }^{18}$ The computations were done using PDP-10 and IBM 360 computers.

\section{Crystal Structure}

According to X-ray diffraction studies, ${ }^{19,20}$ the unit cell of PG I contains pleated sheet antiparallel chains and consists of four asymmetric units (peptide groups). The crystal structure and the dimensions adopted in the present calculations are shown in Figure 1. The structural parameters ${ }^{21}$ are listed in Table $\mathrm{I}$. The translation along the chain axis was taken as $3.45 \AA$ per peptide group, which corresponds to bond rotation angles of $\varphi(\mathrm{N}-\mathrm{C})=-140.15^{\circ}$ and $\psi\left(\mathrm{C}-\mathrm{C}^{\prime}\right)=135: 88^{\circ}$. The distance between the two neighboring chain axes in a sheet was taken as $4.70 \AA$. 

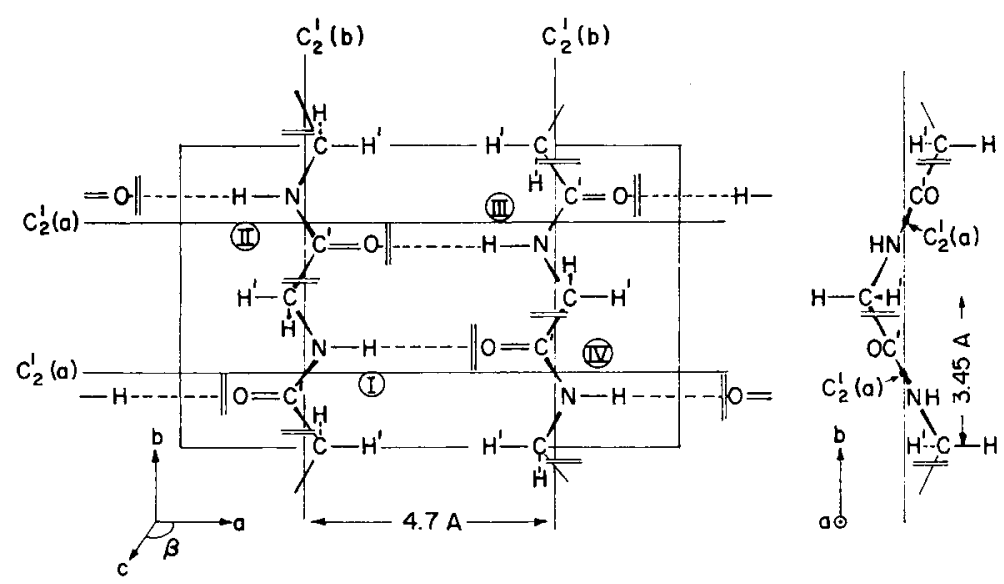

A.

8.

Fig. 1. Structure of crystalline polyglycine I: (A) projected on the $a b$ plane, (B) projected along the $a$ axis.

TABLE I

Structural Parameters for Polyglycine ${ }^{21}$

\begin{tabular}{|c|c|}
\hline \multicolumn{2}{|c|}{ Bond lengths (in $\AA$ ) } \\
\hline $\begin{aligned} r\left(\mathrm{C}-\mathrm{C}^{\prime}\right) & =1.53 \\
r\left(\mathrm{C}^{\prime}-\mathrm{N}\right) & =1.32 \\
r(\mathrm{~N}-\mathrm{C}) & =1.47\end{aligned}$ & $\begin{aligned} r\left(\mathrm{C}^{\prime}=\mathrm{O}\right) & =1.24 \\
r(\mathrm{C}-\mathrm{H}) & =1.07 \\
r(\mathrm{~N}-\mathrm{H}) & =1.00\end{aligned}$ \\
\hline \multicolumn{2}{|c|}{ Bond angles } \\
\hline $\begin{array}{l}\angle \mathrm{C}-\mathrm{C}^{\prime}-\mathrm{N}=114^{\circ} \\
\angle \mathrm{C}^{\prime}-\mathrm{N}-\mathrm{C}=123^{\circ} \\
\angle \mathrm{N}-\mathrm{C}-\mathrm{C}^{\prime}=\text { tetrahedral }\end{array}$ & $\begin{array}{l}\angle \mathrm{C}-\mathrm{C}^{\prime}=\mathrm{O}=121^{\circ} \\
\angle \mathrm{C}^{\prime}-\mathrm{N}-\mathrm{H}=123^{\circ} \\
\angle \mathrm{N}-\mathrm{C}-\mathrm{H}=\mathrm{C}^{\prime}-\mathrm{C}-\mathrm{H}= \\
\quad \text { tetrahedral }\end{array}$ \\
\hline
\end{tabular}

The only interchain interaction considered in the calculations was the $\mathrm{N}-\mathrm{H}---\mathrm{O}=\mathrm{C}^{\prime}$ hydrogen bond. Accordingly, the distance between neighboring sheets, that is the dimension along the $c$ axis, and the magnitude of the angle $\beta$ of the monoclinic unit cell are of no importance. It was assumed that a given peptide group and the peptide group to which it is hydrogen bonded lie in the same plane together with the hydrogen bonds. In other words, the $b$ and $c$ coordinates of the methylene carbon of unit $I$ are assumed to be the same as those of unit III in Figure 1. For this structure the angles $\mathrm{C}^{\prime}=\mathrm{O}---\mathrm{H}$ and $\mathrm{N}-\mathrm{H}---\mathrm{O}$ are $175.5^{\circ}$ and $176.0^{\circ}$, respectively, $\mathrm{C}^{\prime}=\mathrm{O}-\cdots-\mathrm{H}-\mathrm{N}$ being almost linear.

\section{Internal Coordinates and Local Symmetry Coordinates}

Internal coordinates for a peptide group of crystalline PG I are given in Table II. In this table, $\Delta r$ and $\Delta \theta$ are increases in bond length and bond angle, respectively; $\Delta \boldsymbol{\gamma}_{\|}$and $\Delta \gamma_{\perp}$ are a pair of bending coordinates per- 
TABLE II

Internal Coordinates for One Peptide Group of Crystalline Polyglycine I

$\begin{array}{ll}R_{1}=\Delta r\left(\mathrm{C}-\mathrm{C}^{\prime}\right) & R_{16}=\Delta \theta(\mathrm{N}-\mathrm{C}-\mathrm{H}) \\ R_{2}=\Delta r\left(\mathrm{C}^{\prime}-\mathrm{N}\right) & R_{17}=\Delta \theta\left(\mathrm{N}-\mathrm{C}-\mathrm{H}^{\prime}\right) \\ R_{3}=\Delta r(\mathrm{~N}-\mathrm{C}) & R_{18}=\Delta \theta\left(\mathrm{C}^{\prime}-\mathrm{C}-\mathrm{H}\right) \\ R_{4}=\Delta r\left(\mathrm{C}^{\prime}=\mathrm{O}\right) & R_{19}=\Delta \theta\left(\mathrm{C}^{\prime}-\mathrm{C}-\mathrm{H}^{\prime}\right) \\ R_{5}=\Delta r(\mathrm{~N}-\mathrm{H}) & R_{20}=\Delta \theta\left(\mathrm{H}-\mathrm{C}-\mathrm{H}^{\prime}\right) \\ R_{6}=\Delta r(\mathrm{C}-\mathrm{H}) & R_{21}=\Delta \gamma \|\left(\mathrm{C}^{\prime}=\mathrm{O} \cdots \mathrm{H}\right) \\ R_{7}=\Delta r\left(\mathrm{C}-\mathrm{H}^{\prime}\right) & R_{22}=\Delta \gamma \perp\left(\mathrm{C}^{\prime}=\mathrm{O} \cdots \mathrm{H}\right) \\ R_{8}=\Delta r(\mathrm{H} \cdots \mathrm{O}) & R_{23}=\Delta \gamma \|(\mathrm{N}-\mathrm{H} \cdots \mathrm{O}) \\ R_{9}=\Delta \theta\left(\mathrm{C}-\mathrm{C}^{\prime}-\mathrm{N}\right) & R_{24}=\Delta \gamma \perp(\mathrm{N}-\mathrm{H} \cdots \mathrm{O}) \\ R_{10}=\Delta \theta(\mathrm{C}-\mathrm{N}-\mathrm{C}) & R_{25}=\Delta \omega\left(\mathrm{O}=\mathrm{C}^{\prime} \backslash \mathrm{C}\right) \\ \left.R_{11}=\Delta \theta(\mathrm{N}-\mathrm{C}-\mathrm{C})^{\prime}\right) & R_{26}=\Delta \omega(\mathrm{H}-\mathrm{N}\langle\mathrm{C}) \\ R_{12}=\Delta \theta\left(\mathrm{C}-\mathrm{C}^{\prime}=\mathrm{O}\right) & R_{27}=\Delta t\left(\mathrm{C}-\mathrm{C}^{\prime}\right) \\ R_{13}=\Delta \theta\left(\mathrm{N}-\mathrm{C}^{\prime}=\mathrm{O}\right) & R_{28}=\Delta t\left(\mathrm{C}^{\prime}-\mathrm{N}\right) \\ R_{14}=\Delta \theta(\mathrm{C}-\mathrm{N}-\mathrm{H}) & R_{29}=\Delta t(\mathrm{~N}-\mathrm{C}) \\ R_{15}=\Delta \theta(\mathrm{C}-\mathrm{N}-\mathrm{H}) & \end{array}$

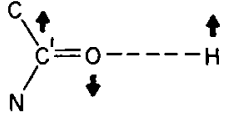

$\Delta r_{11}\left(C^{\prime}=0---H\right)$

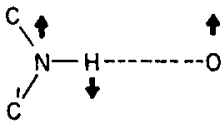

$\Delta \gamma_{||}(\mathrm{N}-\mathrm{H}-\mathrm{-O})$

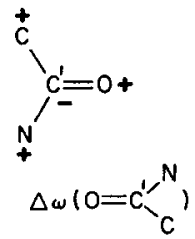

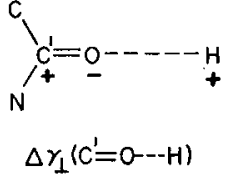

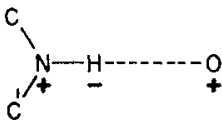

$\Delta r_{\perp}(\mathrm{N}-\mathrm{H}-\mathrm{-O})$

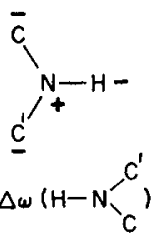

Fig. 2. Definitions of positive directions for some internal coordinates.

pendicular to each other for a linear group such as $\mathrm{N}-\mathrm{H}---0 ;{ }^{22} \quad \Delta \omega$ is an out-of-plane bending coordinate for a trigonal planar group $\mathrm{B}-\mathrm{A}<\mathrm{C}$, defined by $\Delta \omega=\Delta \alpha_{\mathrm{B}} \sin (\angle \mathrm{C}-\mathrm{A}-\mathrm{D})$ where $\Delta \alpha_{\mathrm{B}}$ is a displacement of the bond $\mathbf{B}-\mathbf{A}$ from the plane $\mathbf{C}-\mathbf{A}-\mathrm{D}$; and $\Delta t$ is the sum of all torsional coordinates associated with a bond divided by the number of terms in the $\operatorname{sum}^{23}$ (e.g., $\Delta t=\left(\Delta \tau_{\mathrm{CC}^{\prime} \mathrm{NC}}+\Delta \tau_{\mathrm{CC}^{\prime} \mathrm{NH}}+\Delta \tau_{\mathrm{OC}{ }^{\prime} \mathrm{NC}}+\Delta \tau_{\mathrm{OC}}{ }^{\prime N H}\right) / 4$ for the $\mathrm{C}^{\prime}-\mathrm{N}$ bond, $\Delta \tau_{\mathrm{ABCD}}$ being the increase in the torsional angle for $\mathrm{AB}-\mathrm{CD}$ 
TABLE III

Local Symmetry Coordinates ${ }^{\mathbf{a}}$ for One Peptide Group of Crystalline Polyglycine I

\begin{tabular}{|c|c|}
\hline$S_{1}=R_{3}$ & $\mathrm{~N}-\mathrm{C}$ stretch \\
\hline$S_{2}=R_{\mathrm{I}}$ & $\mathrm{C}-\mathrm{C}^{\prime}$ stretch \\
\hline$S_{3}=R_{2}$ & $\mathrm{C}^{\prime}-\mathrm{N}$ stretch \\
\hline$S_{4}=R_{4}$ & $\mathrm{C}^{\prime}=\mathrm{O}$ stretch \\
\hline$S_{6}=R_{5}$ & $\mathrm{~N}-\mathrm{H}$ stretch \\
\hline$S_{6}=\left(R_{6}+R_{7}\right) / 2^{1 / 2}$ & $\mathrm{CH}_{2}$ sym. stretch \\
\hline$S_{7}=\left(R_{6}-R_{7}\right) 12^{1 / 2}$ & $\mathrm{CH}_{2}$ asym. stretch \\
\hline$S_{8}=\left(2 \cdot R_{10}-R_{14}-R_{16}\right) / 6^{1 / 2}$ & $\mathrm{C}^{\prime} \mathrm{NC}$ deform. \\
\hline$S_{9}=\left(5 \cdot R_{11}-R_{16}-R_{17}-R_{18}-R_{19}-R_{20}\right) / 30^{1 / 2}$ & $\mathrm{NCC}^{\prime}$ deform. \\
\hline$S_{10}=\left(2 \cdot R_{9}-R_{12}-R_{13}\right) / 6^{1 / 2}$ & $\mathrm{CC}^{\prime} \mathbf{N}$ deform. \\
\hline$S_{11}=\left(R_{12}-R_{13}\right) / 2^{1 / 2}$ & $\mathrm{C}^{\prime}=\mathrm{O}$ ip bend \\
\hline$S_{12}=\left(R_{14}-R_{16}\right) / 2^{1 / 2}$ & $\mathrm{~N}-\mathrm{H}$ ip bend \\
\hline$S_{13}=\left(4 \cdot R_{20}-R_{16}-R_{17}-R_{18}-R_{19}\right) / 20^{1 / 2}$ & $\mathrm{CH}_{2}$ bend \\
\hline$S_{14}=\left(R_{16}+R_{17}-R_{18}-R_{19}\right) / 2$ & $\mathrm{CH}_{2}$ wag \\
\hline$S_{16}=\left(R_{16}-R_{17}-R_{18}+R_{19}\right) / 2$ & $\mathrm{CH}_{2}$ twist \\
\hline$S_{16}=\left(R_{16}-R_{17}+R_{18}-R_{19}\right) / 2$ & $\mathrm{CH}_{2}$ rock \\
\hline$S_{17}=R_{25}$ & $\mathrm{C}^{\prime}=\mathrm{O}$ op bend \\
\hline$S_{18}=R_{26}$ & $\mathrm{~N}-\mathrm{H}$ op bend \\
\hline$S_{19}=R_{29}$ & $\mathrm{~N}-\mathrm{C}$ torsion \\
\hline$S_{20}=R_{27}$ & $\mathrm{C}-\mathrm{C}^{\prime}$ torsion \\
\hline$S_{21}=R_{28}$ & $\mathrm{C}^{\prime}-\mathrm{N}$ torsion \\
\hline$S_{22}=R_{8}$ & $\mathrm{H} \ldots \mathrm{O}$ stretch \\
\hline$S_{23}=R_{21}$ & $\mathrm{C}^{\prime}=\mathrm{O} \cdots \mathrm{H}$ ip bend \\
\hline$S_{24}=R_{22}$ & $\mathrm{C}^{\prime}=\mathrm{O} \cdots \mathrm{H}$ op bend \\
\hline$S_{25}=R_{23}$ & $\mathrm{~N}-\mathrm{H} \cdots \mathrm{O}$ ip bend \\
\hline$S_{26}=R_{24}$ & $\mathrm{~N}-\mathrm{H} \cdots \mathrm{O}$ op bend \\
\hline
\end{tabular}

a Here ip denotes vibrations in the plane of the amide group and op denotes those perpendicular to this plane.

measured in the clockwise direction). Positive directions for the linear bending and the out-of-plane bending coordinates were defined as shown in Figure 2. Local symmetry coordinates for one peptide group, which are constructed from the internal coordinates defined above, are given in Table III.

\section{Optically Active Symmetry Coordinates and Selection Rules}

The optically active symmetry coordinates for the whole crystal are classified into four symmetry species, $A, B_{1}, B_{2}$, and $B_{3}$. These are shown in Table IV, which was taken from Ref. 15. The symmetry coordinates for each species are given by

$$
\begin{aligned}
& \mathbf{S}(\mathrm{A})=c \sum_{i}\left(\mathbf{S}_{\mathrm{I}}^{i}+\mathbf{S}_{\mathrm{II}}^{i}+\mathbf{S}_{\mathrm{III}}^{i}+\mathbf{S}_{\mathrm{IV}}^{i}\right) \\
& \mathbf{S}\left(\mathrm{B}_{1}\right)=c \sum_{i}\left(\mathbf{S}_{\mathrm{I}}^{i}+\mathbf{S}_{\mathrm{II}}^{i}-\mathbf{S}_{\mathrm{III}}^{i}-\mathbf{S}_{\mathrm{IV}}^{i}\right) \\
& \mathbf{S}\left(\mathrm{B}_{2}\right)=c \sum_{i}\left(\mathbf{S}_{\mathrm{I}}^{i}-\mathbf{S}_{\mathrm{II}}^{i}-\mathbf{S}_{\mathrm{III}}^{i}+\mathbf{S}_{\mathrm{IV}}^{i}\right) \\
& \mathbf{S}\left(\mathrm{B}_{3}\right)=c \sum_{i}\left(\mathbf{S}_{\mathrm{I}}^{i}-\mathbf{S}_{\mathrm{II}}^{i}-\mathbf{S}_{\mathrm{III}}^{i}-\mathbf{S}_{\mathrm{IV}}^{i}\right)
\end{aligned}
$$


TABLE IV

Symmetry Species and Selection Rules for Crystalline Polyglycine $I^{15}$

\begin{tabular}{|c|c|c|c|c|c|c|}
\hline \multirow[b]{2}{*}{ Species } & \multirow{2}{*}{$\begin{array}{c}\text { Phase } \\
\text { differences }\end{array}$} & \multirow{2}{*}{\multicolumn{2}{|c|}{$\frac{\text { Symmetry }}{C_{2}^{1}(\mathbf{a}) C_{2}^{1}(\mathrm{~b})}$}} & \multirow{2}{*}{$\begin{array}{l}\text { Number } \\
\text { of modes }\end{array}$} & \multicolumn{2}{|c|}{ Selection rules } \\
\hline & & & & & Raman & Infraredc \\
\hline A & $(0,0)$ & + & + & 21 & active & inactive \\
\hline$B_{1}$ & $(0, \pi)$ & - & + & 20 & active & active $(\|)$ \\
\hline $\mathrm{B}_{2}$ & $(\pi, 0)$ & + & - & 20 & active & $\operatorname{active}(1)$ \\
\hline $\mathbf{B}_{3}$ & $(\pi, \pi)$ & - & - & 20 & active & active $(\perp)$ \\
\hline
\end{tabular}

a The first and the second variables are the phase angles between intrachain and interchain peptide group motions, respectively.

${ }^{b}$ The plus and minus signs indicate that the vibrations are symmetric and antisymmetric, respectively, with respect to the symmetry element.

- The $\|$ and $\perp$ signs indicate parallel and perpendicular dichroism, respectively.

where $\mathbf{S}_{\mathrm{I}}^{i}, \mathbf{S}_{\mathrm{II}}^{i}, \mathbf{S}_{\mathrm{III}}^{i}$, and $\mathbf{S}_{\mathrm{IV}}^{i}$ are vectors consisting of the local symmetry coordinates defined by Table III for the peptide groups (I, II, III, and IV as designated in Fig. 1) of the $i$ th unit cell. The sums are taken over all unit cells, and $c$ is a normalization factor.

Selection rules and the dichroic nature of the infrared bands are also given in Table IV.

\section{Valence Force Field}

Force constants corresponding to the following types of potential energy terms were considered in the present calculations (see Fig. 3).

1. Potential energy for each internal coordinate:

$$
V(a)=1 / 2 f(a) \cdot(\Delta a)^{2}
$$

where $\Delta a=\Delta r, \Delta \theta, \Delta \gamma, \Delta \omega$, or $\Delta t$ given in Table II, and $V(a)$ and $f(a)$ are the relevant potential energy and force constant, respectively. Similar notations are used in the following. (The units of $f(a)$ are mdyn $/ \AA$ for the stretching coordinate and mdyn- $\AA$ for the other coordinates).

2. Interaction energy between the bond stretching coordinates for a pair of bonds which share a common atom:

$$
V\left(r_{1}, r_{2}\right)=f\left(r_{1}, r_{2}\right) \cdot \Delta r_{1} \cdot \Delta r_{2}
$$

$\left(f\left(r_{1}, r_{2}\right)\right.$ is in units of mdyn $\left./ \AA\right)$.

3. Interaction energy between the bending coordinate for a bond angle and the stretching coordinate for a bond attached to the apex atom of the angle:

$$
V(\Delta r, \Delta \theta)=f(r, \theta) \cdot \Delta r \cdot \Delta \theta
$$

$(f(r, \theta)$ is in units of mdyn).

4. Interaction energy between the bending coordinates for a pair of bond angles; between the out-of-plane bending coordinates for a pair of trigonal planar groups; or between the bending coordinate for a bond angle and the 

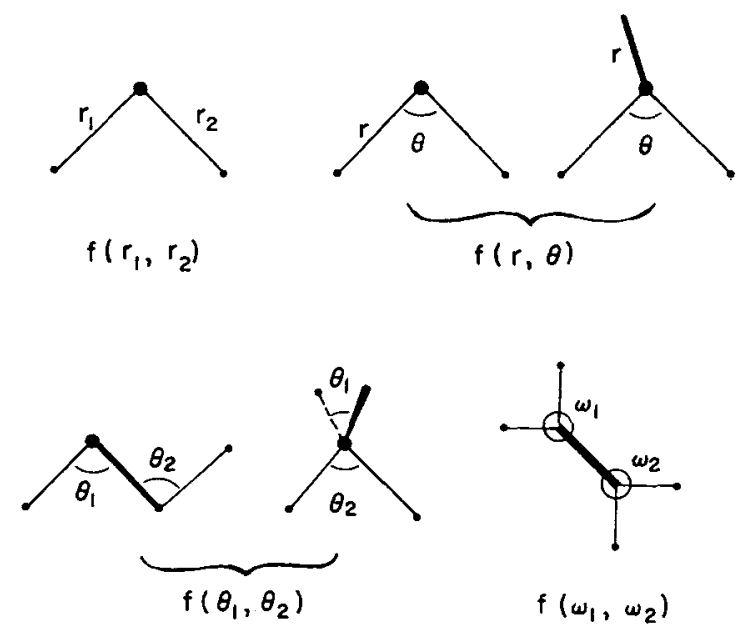

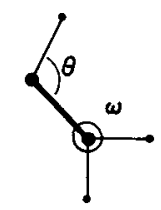

$f(\theta, \omega)$

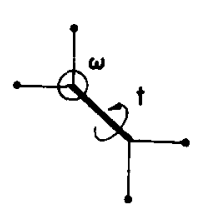

$f(\omega, f)$

Fig. 3. Definitions of interaction force constants.

out-of-plane bending coordinate for a planar group which share a common bond and/or a common apex atom:

$$
\begin{aligned}
& V\left(\theta_{1}, \theta_{2}\right)=f\left(\theta_{1}, \theta_{2}\right) \Delta \cdot \theta_{1} \cdot \Delta \theta_{2}, \\
& V\left(\omega_{1}, \omega_{2}\right)=f\left(\omega_{1}, \omega_{2}\right) \cdot \Delta \omega_{1} \cdot \Delta \omega_{2}, \quad \text { or } \\
& V(\theta, \omega)=f(\theta, \omega) \cdot \Delta \theta \cdot \Delta \omega .
\end{aligned}
$$

(the $f$ 's in Eq. (5) are in units of mdyn- $\AA$ ).

5. Interaction energy between the torsional coordinate for a $\mathrm{C}^{\prime}-\mathrm{N}$ bond and each of the out-of-plane bending coordinates for the<smiles>[CH]NC</smiles>

groups attached to the $\mathrm{C}^{\prime}-\mathrm{N}$ bond:

$$
V(\omega, t)=f(\omega, t) \cdot \Delta \omega \cdot \Delta t
$$

$(f(\omega, t)$ is in units of mdyn- $\AA$ ). 
No interaction terms were considered for the interchain coordinates except for the one between the $\mathrm{C}^{\prime}=\mathrm{O}$ stretching and $\mathrm{O}---\mathrm{H}$ stretching coordinates in the following part of the structure ${ }^{15,16}$ :<smiles></smiles>

The interaction energy between the $\mathrm{C}-\mathrm{H}$ or $\mathrm{N}-\mathrm{H}$ stretching coordinate and any other coordinate was also neglected.

Since the angle bending coordinates adopted for the $\mathrm{C}-\mathrm{C}^{\prime} \mathrm{O}-\mathrm{N}$, $\mathrm{C}^{\prime}-\mathrm{NH}-\mathrm{C}$, and $\mathrm{N}-\mathrm{CH}_{2}-\mathrm{C}^{\prime}$ groups are not all independent, the force constants introduced above are not all independent. Instead, only a certain number of linear combinations are independent. The potential energy matrix based on the symmetry coordinates, for which the local redundancies in each of the above three groups are removed, must be expressed in terms of such independent linear combinations only. For example, we do not need the six force constants $f\left(\mathrm{CC}^{\prime} \mathrm{N}\right), f\left(\mathrm{CC}^{\prime}=0\right), f$ $\left(\mathrm{NC}^{\prime}=\mathrm{O}\right), f\left(\mathrm{CC}^{\prime} \mathrm{N}, \mathrm{CC}^{\prime}=0\right), f\left(\mathrm{CC}^{\prime} \mathrm{N}, \mathrm{NC}^{\prime}=\mathrm{O}\right)$, and $f\left(\mathrm{CC}^{\prime}=\mathrm{O}, \mathrm{NC}^{\prime}=\mathrm{O}\right)$ for the $\mathrm{C}-\mathrm{C}^{\prime} \mathrm{O}-\mathrm{N}$ group, but only the following three linear combinations:

$f\left(\mathrm{CC}^{\prime} \mathrm{N}\right)-f\left(\mathrm{CC}^{\prime} \mathrm{N}, \mathrm{CC}^{\prime}=\mathrm{O}\right)-f\left(\mathrm{CC}^{\prime} \mathrm{N}, \mathrm{NC}^{\prime}=\mathrm{O}\right)+f\left(\mathrm{CC}^{\prime}=\mathrm{O}, \mathrm{NC}^{\prime}=\mathrm{O}\right)$, $f\left(\mathrm{CC}^{\prime}=\mathrm{O}\right)-f\left(\mathrm{CC}^{\prime} \mathrm{N}, \mathrm{CC}^{\prime}=\mathrm{O}\right)$

$$
+f\left(\mathrm{CC}^{\prime} \mathrm{N}, \mathrm{NC}^{\prime}=\mathrm{O}\right)-f\left(\mathrm{CC}^{\prime}=\mathrm{O}, \mathrm{NC}^{\prime}==\mathrm{O}\right),
$$

and

$f\left(\mathrm{NC}^{\prime}=\mathrm{O}\right)+f\left(\mathrm{CC}^{\prime} \mathrm{N}, \mathrm{CC}^{\prime}=\mathrm{O}\right)$

$$
-f\left(\mathrm{CC}^{\prime} \mathrm{N}, \mathrm{NC}^{\prime}=\mathrm{O}\right)-f\left(\mathrm{CC}^{\prime}=\mathrm{O}, \mathrm{NC}^{\prime}=\mathrm{O}\right) \text {. }
$$

We have taken the above linear combinations as force constants, and represented them by $f\left(\mathrm{CC}^{\prime} \mathrm{N}\right), f\left(\mathrm{CC}^{\prime}=0\right)$, and $f\left(\mathrm{NC}^{\prime}=0\right)$, respectively. That is, the force constants $f\left(\mathrm{CC}^{\prime} \mathrm{N}\right)$ etc used hereafter include some minor interaction terms such as $f^{\prime}\left(\mathrm{CC}^{\prime} \mathrm{N}, \mathrm{CC}^{\prime}=\mathrm{O}\right)$. Similar modifications were made for the force constants of the $\mathrm{C}^{\prime}-\mathrm{NH}-\mathrm{C}$ and $\mathrm{N}-\mathrm{CH}_{2}-\mathrm{C}^{\prime}$ groups. As a result, the seventy-eight force constants listed in Table $V$ were adopted for the PG I crystal.

The interdependence of force constants described above comes from geometrical features. Isotopic substitution does not affect it.

\section{Adjustment of Force Constants}

The force constants were adjusted by considering (a) the infrared data of $-\mathrm{NHCH}_{2} \mathrm{CO}-, \quad \mathrm{N}^{15} \mathrm{HCH}_{2} \mathrm{CO}-,-\mathrm{NDCH}_{2} \mathrm{CO}-,-\mathrm{NHCD}_{2} \mathrm{CO}$-, and $-\mathrm{NDCD}_{2} \mathrm{CO}$ - reported by Suzuki, Iwashita, Shimanouchi, and Tsuboi, ${ }^{3}$ (b) the far infrared data on $-\mathrm{NHCH}_{2} \mathrm{CO}-$ obtained in the present work, and (c) the Raman data on $-\mathrm{NHCH}_{2} \mathrm{CO}$ - reported by Small, Fanconi, and Peticolas. ${ }^{6}$ 
Our assignments of observed bands are almost the same as those for a single chain in the previous studies. ${ }^{3,6,7,14,16}$ The infrared bands were assigned to $B_{1}$ modes, $B_{2}$ modes, and/or $B_{3}$ out-of-plane modes, since $A$ modes are infrared-inactive and $\mathrm{B}_{3}$ in-plane modes are expected to be very weak in the infrared spectrum (as pointed out by Fukushima, Ideguchi, and Miyazawa ${ }^{14}$ ). The infrared dichroism data of Elliott and Malcolm ${ }^{1}$ were also considered, and all of the assignments were made consistent for all isotopic molecules. The Raman bands of $-\mathrm{NHCH}_{2} \mathrm{CO}-$ were assigned in a similar way.

Values for the interchain force constants were chosen in the following way. A broad band centered at ca $140 \mathrm{~cm}^{-1}$ was observed by Krimm and Kuroiwa, ${ }^{24}$ and also reported by Gupta, Trevino, and Boutin. ${ }^{7}$ Simjlar bands were observed in the $110 \sim 130 \mathrm{~cm}^{-1}$ region for several poly(- $\alpha$-amino acids) in the $\beta$-form by Itoh, Shimanouchi, and Oya. ${ }^{25}$ These bands were assigned to the translational lattice vibration of the $B_{3}$ species, which is approximately the $\mathrm{O}---\mathrm{H}$ stretching vibration. From the observed frequency of ca $140 \mathrm{~cm}^{-1}, f\left(\mathrm{O}_{-}--\mathrm{H}\right.$ str. $)=0.2 \mathrm{mdyn} / \AA$ was derived. The bending force constants for the $\mathrm{C}^{\prime}=\mathrm{O}--\mathrm{H}$ and $\mathrm{N}-\mathrm{H}---\mathrm{O}$ groups were transferred from $N$-methylacetamide studied by Itoh and Shimanouchi. ${ }^{26}$ The interaction force constant $f\left(\mathrm{C}^{\prime}=\mathrm{O}\right.$ str., $\mathrm{O}---\mathrm{H}$ str. $)$ in the structure below was introduced by Fukushima and Miyazawa ${ }^{16}$ in<smiles></smiles>

order to reproduce the $\nu(0, \pi)-\nu(\pi, 0)$ splitting of the amide I frequencies. (Such an interaction term is probably physically justifiable, since the resonant nature of the peptide group implies that changes in the $\mathrm{C}^{\prime}=\mathrm{O}$ bond will influence the electronic distribution in the $\mathrm{N}-\mathrm{H}$ bond, which in turn will affect the $\mathrm{H}---\mathrm{O}$ stretching vibration). In the present calculations two values were assumed, 0.0 and $0.45 \mathrm{mdyn} / \AA$, the latter having been used by Fukushima and Miyazawa.

With respect to the seventy-two intrachain force constants, the eigenvalues and eigenvectors of the $\tilde{\mathbf{J}} \mathbf{W} \mathbf{J}$ matrix (where $\mathbf{J}$ is the Jacobian matrix defined by $J_{i j}=\partial_{\nu_{i}} / \partial f_{j}, \tilde{\mathbf{J}}$ is the transpose of $\mathbf{J}$, and $\mathbf{W}$ is a diagonal weighting matrix for the frequencies) indicate that more than thirty force constants are badly correlated with other force constants and that most of the former are associated with skeletal vibrations. This is natural because there are thirty-five force constants directly associated with skeletal vibrations while only fifteen observed frequencies serve to determine them (note that the skeletal modes of deuterated molecules are almost the same as those of the normal molecule, and their observed frequencies therefore cannot be considered as independent data for determining the force constants). After several least-squares adjustment trials under various conditions, twenty-nine force constants (of which four pairs were set equal to 
TABLE V Force Constants for Polyglycine I

\begin{tabular}{|c|c|c|c|}
\hline \multirow[b]{2}{*}{ Force constant } & \multicolumn{3}{|c|}{ Value } \\
\hline & Set I-1/ & Set I-2 & Set I-3 \\
\hline 1. $f(\mathrm{~N}-\mathrm{C})^{\mathrm{b}}$ & $5.043(0.156)^{c}$ & $5.078(0.144)$ & $5.025(0.170)$ \\
\hline 2. $f\left(\mathrm{C}-\mathrm{C}^{\prime}\right)$ & $4.509(0.356)$ & $4.520(0.304)$ & $4.419(0.372)$ \\
\hline 3. $f\left(\mathrm{C}^{\prime}-\mathrm{N}\right)$ & $6.299(0.515)$ & $6.111(0.440)$ & $6.304(0.536)$ \\
\hline 4. $f\left(\mathrm{C}^{\prime}=0\right)$ & $9.549(0.174)$ & $9.436(0.153)$ & $9.496(0.183)$ \\
\hline 5. $f(\mathrm{~N}-\mathrm{H})$ & $5.827(0.032)$ & $5.825(0.028)$ & $5.998(0.034)$ \\
\hline 6. $f(\mathrm{C}-\mathrm{H})$ & $4.564(0.016)$ & $4.564(0.014)$ & $4.564(0.017)$ \\
\hline 7. $f\left(\mathrm{C}^{\prime} \mathrm{NC}\right)$ & $0.787(0.164)$ & $0.788(0.151)$ & $1.050(0.199)$ \\
\hline 8. $f\left(\mathrm{NCC}^{\prime}\right)$ & 1.00 & $* * *_{\mathrm{d}}$ & $* * *$ \\
\hline 9. $f\left(\mathrm{CC}^{\prime} \mathrm{N}\right)$ & $1.40 \dagger$ & $* * *$ & $* * *$ \\
\hline $\left.\begin{array}{l}\text { 10. } f\left(\mathrm{CC}^{\prime}=\mathrm{O}\right) \\
\text { 11. } f\left(\mathrm{NC}^{\prime}=\mathrm{O}\right)\end{array}\right\}$ & $1.246(0.098)$ & $1.274(0.091)$ & $1.269(0.106)$ \\
\hline 12. $f\left(\mathrm{C}^{\prime} \mathrm{NH}\right)$ & & & \\
\hline 13. $f(\mathrm{CNH})\}$ & $0.463(0.015)$ & $0.466(0.014)$ & $0.496(0.016)$ \\
\hline 14. $f(\mathrm{NCH})$ & $0.715(0.032)$ & $0.717(0.028)$ & $0.699(0.033)$ \\
\hline 15. $f\left(\mathrm{C}^{\prime} \mathrm{CH}\right)$ & $0.684(0.029)$ & $0.682(0.025)$ & $0.673(0.032)$ \\
\hline 16. $f(\mathrm{HCH})$ & $0.581(0.013)$ & $0.584(0.012)$ & $0.588(0.014)$ \\
\hline 17. $f\left(\mathrm{C}^{\prime}=\mathrm{O}\right.$ op $)$ & $0.594(0.045)$ & $0.595(0.039)$ & $0.614(0.046)$ \\
\hline 18. $f(\mathrm{~N}-\mathrm{H}$ op $)$ & $0.171(0.018)$ & $0.170(0.016)$ & $0.191(0.038)$ \\
\hline 19. $f(\mathrm{~N}-\mathrm{C}$ tor $)$ & 0.037 & $* * *$ & $* * *$ \\
\hline 20. $f\left(\mathrm{C}-\mathrm{C}^{\prime}\right.$ tor $)$ & 0.037 & $* * *$ & $* * *$ \\
\hline 21. $f\left(\mathrm{C}^{\prime}-\mathrm{N}\right.$ tor $)$ & $0.579(0.053)$ & $0.580(0.048)$ & $0.598(0.087)$ \\
\hline 22. $f\left(\mathrm{~N}-\mathrm{C}, \mathrm{C}-\mathrm{C}^{\prime}\right)$ & 0.3 & $* * *$ & $* * *$ \\
\hline 23. $f\left(\mathrm{C}-\mathrm{C}^{\prime}, \mathrm{C}^{\prime}-\mathrm{N}\right)$ & 0.3 & *** & $* * *$ \\
\hline 24. $f\left(\mathrm{C}^{\prime}-\mathrm{N}, \mathrm{N}-\mathrm{C}\right)$ & 0.3 & $* * *$ & $* * *$ \\
\hline 25. $f\left(\mathrm{C}-\mathrm{C}^{\prime}, \mathrm{C}^{\prime}=0\right)$ & 0.5 & $* * *$ & $* * *$ \\
\hline 26. $f\left(\mathrm{C}^{\prime}-\mathrm{N}, \mathrm{C}^{\prime}=\mathrm{O}\right)$ & 0.5 & $* * *$ & $* * *$ \\
\hline 27. $f\left(\mathrm{C}^{\prime}-\mathrm{N}, \mathrm{C}^{\prime} \mathrm{NC}\right)$ & 0.3 & $* * *$ & *** \\
\hline 28. $f\left(\mathrm{~N}-\mathrm{C}, \mathrm{C}^{\prime} \mathrm{NC}\right)$ & 0.3 & $* * *$ & $* * *$ \\
\hline 29. $f\left(\mathrm{~N}-\mathrm{C}, \mathrm{NCC}^{\prime}\right)$ & 0.3 & $* * *$ & $* * *$ \\
\hline 30. $f\left(\mathrm{C}-\mathrm{C}^{\prime}, \mathrm{NCC}^{\prime}\right)$ & 0.3 & *** & *** \\
\hline 31. $f\left(\mathrm{C}-\mathrm{C}^{\prime}, \mathrm{CC}^{\prime} \mathrm{N}\right)$ & 0.3 & $* * *$ & $* * *$ \\
\hline 32. $f\left(\mathrm{C}^{\prime}-\mathrm{N}, \mathrm{CC}^{\prime} \mathrm{N}\right)$ & 0.3 & **** & *** \\
\hline 33. $f\left(\mathrm{C}-\mathrm{C}^{\prime}, \mathrm{CC}^{\prime}=0\right)$ & 0.2 & $* * *$ & $* * *$ \\
\hline 34. $f\left(\mathrm{C}^{\prime}-\mathrm{N}, \mathrm{NC}^{\prime}=\mathrm{O}\right)$ & 0.2 & $* * *$ & $* * *$ \\
\hline 35. $f\left(\mathrm{C}^{\prime}=\mathrm{O}, \mathrm{CC}^{\prime}=\mathrm{O}\right)$ & 0.45 & $* * *$ & $* * *$ \\
\hline 36. $f\left(\mathrm{C}^{\prime}=\mathrm{O}, \mathrm{NC}^{\prime}=\mathrm{O}\right)$ & 0.45 & $* * *$ & $* * *$ \\
\hline $\left.\begin{array}{l}\text { 37. } f\left(\mathrm{C}^{\prime}-\mathrm{N}, \mathrm{C}^{\prime} \mathrm{NH}\right) \\
\text { 38. } f(\mathrm{~N}-\mathrm{C}, \mathrm{CNH})\end{array}\right\}$ & $0.294(0.061)$ & $0.302(0.057)$ & $0.298(0.067)$ \\
\hline 39. $f(\mathrm{~N}-\mathrm{C}, \mathrm{NCH})$ & $0.517(0.043)$ & $0.532(0.038)$ & $0.520(0.046)$ \\
\hline $\left.\begin{array}{l}\text { 40. } f\left(\mathrm{~N}-\mathrm{C}, \mathrm{C}^{\prime} \mathrm{CH}\right) \\
\text { 41. } f\left(\mathrm{C}-\mathrm{C}^{\prime}, \mathrm{NCH}\right)\end{array}\right\}$ & $0.026(0.051)$ & $0.036(0.041)$ & $0.044(0.050)$ \\
\hline 42. $f\left(\mathrm{C}-\mathrm{C}^{\prime}, \mathrm{C}^{\prime} \mathrm{CH}\right)$ & $0.205(0.068)$ & $0.217(0.058)$ & $0.225(0.073)$ \\
\hline 43. $f\left(\mathrm{C}^{\prime} \mathrm{NC}, \mathrm{NCC}^{\prime}\right)$ & 0.0 & $* * *$ & $* * *$ \\
\hline 44. $f\left(\mathrm{NCC}^{\prime}, \mathrm{CC}^{\prime} \mathrm{N}\right)$ & 0.0 & $* * *$ & $* * *$ \\
\hline 45. $f\left(\mathrm{CC}^{\prime} \mathrm{N}, \mathrm{C}^{\prime} \mathrm{NC}\right)$ & 0.0 & $* * *$ & $* * *$ \\
\hline 46. $f\left(\mathrm{NCC}^{\prime}, \mathrm{CC}^{\prime}=\mathrm{O}\right)$ & 0.0 & *** & $* * *$ \\
\hline 47. $f\left(\mathrm{C}^{\prime} \mathrm{NC}, \mathrm{NC}^{\prime}=0\right)$ & 0.0 & *** & $* * *$ \\
\hline 48. $f\left(\mathrm{CC}^{\prime} \mathrm{N}, \mathrm{C}^{\prime} \mathrm{NH}\right)$ & 0.2 & $* * *$ & $* * *$ \\
\hline 49. $f\left(\mathrm{NCC}^{\prime}, \mathrm{CNH}\right)$ & $-0.1 \dagger$ & $* * *$ & $* * *$ \\
\hline 50. $f\left(\mathrm{C}^{\prime} \mathrm{NC}, \mathrm{NCH}\right)$ & 0.0 & *** & $* * *$ \\
\hline 51. $f\left(\mathrm{C}^{\prime} \mathrm{NC}, \mathrm{NCH}^{\prime}\right)$ & 0.0 & *** & $* * *$ \\
\hline 52. $f\left(\mathrm{CC}^{\prime} \mathrm{N}, \mathrm{C}^{\prime} \mathrm{CH}\right)$ & 0.0 & $* * *$ & $* * *$ \\
\hline 53. $f\left(\mathrm{CC}^{\prime} \mathrm{N}, \mathrm{C}^{\prime} \mathrm{CH}^{\prime}\right)$ & 0.0 & *** & $* * *$ \\
\hline 54. $f\left(\mathrm{NCH}, \mathrm{NCH}^{\prime}\right)$ & $0.026(0.028)$ & $0.026(0.026)$ & $0.018(0.030)$ \\
\hline
\end{tabular}


TABLE V (continued)

\begin{tabular}{|c|c|c|c|}
\hline \multirow[b]{2}{*}{ Force constant } & \multicolumn{3}{|c|}{ Value } \\
\hline & Set I-1a & Set I-2 & Set I-3 \\
\hline 55. $f\left(\mathrm{C}^{\prime} \mathrm{CH}, \mathrm{C}^{\prime} \mathrm{CH}^{\prime}\right)$ & $-0.023(0.027)$ & $-0.027(0.025)$ & $-0.022(0.030)$ \\
\hline 56. $f\left(\mathrm{NCH}, \mathrm{C}^{\prime} \mathrm{CH}\right)$ & $0.033(0.018)$ & $0.030(0.015)$ & $0.022(0.018)$ \\
\hline 57. $f(\mathrm{NCH}, \mathrm{HCH})$ & 0.05 & $* * *$ & $* * *$ \\
\hline 58. $f\left(\mathrm{C}^{\prime} \mathrm{CH}, \mathrm{HCH}\right)$ & 0.05 & $* * *$ & $* * *$ \\
\hline 59. $f\left(\mathrm{NC}^{\prime}=\mathrm{O}, \mathrm{C}^{\prime} \mathrm{NH}\right)$ & $0.251(0.072)$ & $0.273(0.071)$ & $0.238(0.081)$ \\
\hline 60. $f\left(\mathrm{CC}^{\prime}=\mathrm{O}, \mathrm{C}^{\prime} \mathrm{CH}\right)$ & $0.1 \dagger$ & $* * *$ & $* * *$ \\
\hline 61. $f\left(\mathrm{CC}^{\prime}=\mathrm{O}, \mathrm{C}^{\prime} \mathrm{CH}^{\prime}\right)$ & 0.0 & $* * *$ & $* * *$ \\
\hline 62. $f(\mathrm{CNH}, \mathrm{NCH})$ & $0.058(0.034)$ & $0.066(0.031)$ & $0.076(0.034)$ \\
\hline 63. $f\left(\mathrm{CNH}, \mathrm{NCH}^{\prime}\right)$ & $0.077(0.033)$ & $0.073(0.028)$ & $0.068(0.036)$ \\
\hline 64. $f\left(\mathrm{C}^{\prime}=\mathrm{O}\right.$ op, $\left.\mathrm{NCC}^{\prime}\right)$ & $-0.05 \dagger$ & $* * *$ & $* * *$ \\
\hline 65. $f\left(\mathrm{C}^{\prime}=\mathrm{O}\right.$ op, $\left.\mathrm{C}^{\prime} \mathrm{CH}\right)$ & $0.1 \dagger$ & $* * *$ & $* * *$ \\
\hline 66. $f\left(\mathrm{C}^{\prime}=\mathrm{O}\right.$ op, $\left.\mathrm{C}^{\prime} \mathrm{CH}^{\prime}\right)$ & 0.0 & $* * *$ & $* * *$ \\
\hline 67. $f\left(\mathrm{~N}-\mathrm{H}\right.$ op, $\left.\mathrm{NCC}^{\prime}\right)$ & 0.0 & $* * *$ & $* * *$ \\
\hline 68. $f(\mathrm{~N}-\mathrm{H}$ op, $\mathrm{NCH})$ & 0.0 & $* * *$ & $* * *$ \\
\hline 69. $f\left(\mathrm{~N}-\mathrm{H}\right.$ op, $\left.\mathrm{NCH}^{\prime}\right)$ & $0.1 \dagger$ & $* * *$ & $* * *$ \\
\hline 70. $f\left(\mathrm{C}^{\prime}=\mathrm{O}\right.$ op, $\mathrm{N}-\mathrm{H}$ op $)$ & $-0.06 \dagger$ & $* * *$ & $* * *$ \\
\hline 71. $f\left(\mathrm{C}^{\prime}=\mathrm{O}\right.$ op, $\mathrm{C}^{\prime}-\mathrm{N}$ tor $)$ & $0.07 \dagger$ & $* * *$ & $* * *$ \\
\hline 72. $f\left(\mathrm{~N}-\mathrm{H}\right.$ op, $\mathrm{C}^{\prime}-\mathrm{N}$ tor $)$ & $-0.13 \dagger$ & $* * *$ & $-0.08 \dagger$ \\
\hline 73. $f(\mathrm{H} \cdots \mathrm{O})$ & 0.2 & $* * *$ & 0.0 \\
\hline 74. $f\left(\mathrm{C}^{\prime}=\mathrm{O} \cdots \mathrm{H}\right.$ ip $)$ & 0.01 & $* * *$ & 0.0 \\
\hline 75. $f\left(\mathrm{C}^{\prime}=\mathrm{O} \cdots \mathrm{H}\right.$ op $)$ & 0.01 & $* * *$ & 0.0 \\
\hline 76. $f(\mathrm{~N}-\mathrm{H} \cdots \mathrm{O} \mathrm{ip})$ & 0.03 & $* * *$ & 0.0 \\
\hline 77. $f(\mathrm{~N}-\mathrm{H} \cdots \mathrm{O}$ op $)$ & 0.03 & $* * *$ & 0.0 \\
\hline 78. $f\left(\mathrm{C}^{\prime}=\mathrm{O}, \mathrm{H} \cdots \mathrm{O}\right)$ & 0.0 & 0.45 & 0.0 \\
\hline
\end{tabular}

a Set I-1 was obtained by assuming $f\left(\mathrm{C}^{\prime}=\mathrm{O}, \mathrm{H} \cdots \mathrm{O}\right)=0.0$, Set I-2 by assuming $f\left(\mathrm{C}^{\prime}=\mathrm{O}, \mathrm{H} \cdots \mathrm{O}\right)=0.45$, and Set I-3 by the single-chain treatment.

b The symbols in the parentheses correspond to the internal coordinates of Table II in the following way:

$$
\begin{aligned}
& \mathrm{A}-\mathrm{B}: \Delta r(\mathrm{~A}-\mathrm{B}) \\
& \mathrm{ABC}: \Delta \theta(\mathrm{A}-\mathrm{B}-\mathrm{C}) \\
& \mathrm{C}^{\prime}=\mathrm{O} \text { op: }: \omega\left(\mathrm{O}=\mathrm{C}^{\prime}\left(\begin{array}{l}
\mathrm{N} \\
\mathrm{C}
\end{array}\right)\right. \\
& \mathrm{N}-\mathrm{H} \text { op: } \Delta \omega\left(\mathrm{H}-\mathrm{N}\left\langle\begin{array}{l}
\mathrm{C}^{\prime} \\
\mathrm{C}
\end{array}\right)\right. \\
& \mathrm{A}-\mathrm{B} \text { tor }: \Delta t(\mathrm{~A}-\mathrm{B}) \\
& \mathrm{A}-\mathrm{B} \cdots \mathrm{C} \text { ip: }: \Delta \gamma \|(\mathrm{A}-\mathrm{B} \cdots \mathrm{C}) \\
& \mathrm{A}-\mathrm{B} \cdots \mathrm{C} \text { op: }: \Delta \gamma_{\perp}(\mathrm{A}-\mathrm{B} \cdots \mathrm{C}) .
\end{aligned}
$$

c The values in the parentheses of the last three columns are the uncertainties in the force constants calculated by

$$
\text { uncertainty in } f_{i}=\left[\frac{\sum_{i} w_{i}\left(\nu_{i}{ }^{\text {obs }}-v_{i}{ }^{\mathrm{cslc}}\right)^{2}}{n_{\mathrm{obs}}-n_{\mathrm{fc}}}\left(\mathbf{A}^{-1}\right)_{i i}\right]^{1 / 2}
$$

where $n_{\mathrm{obs}}$ is the number of observed frequencies, $n_{\mathrm{fc}}$ the number of variable force constants, and $w_{i}=W_{i i}$ and $\mathbf{A}=\tilde{\mathbf{J}} \mathbf{W} \mathbf{J}, \mathbf{W}$ and $\mathbf{J}$ being defined in the text.

The force constants followed by their uncertainties were determined by least squares, those marked by $\uparrow$ were adjusted by trial and error, and other force constants were transferred from amides ${ }^{12}$ and paraffins. ${ }^{27}$

d*** indicates that the value is in the same as in set I-1. 
each other) were determined by least squares, nine more constants were adjusted by estimation, and the remaining thirty-four constants were fixed to zero or to rough values estimated from the valence force field of the amide group ${ }^{12}$ and that of the paraffins. ${ }^{27}$ In carrying out the least-squares adjustment, all observed frequencies were weighted by unity and $\mathrm{N}^{15}$ isotope shifts were weighted by five, except for the shifts of amide I and amide II which were weighted by fifty since they only can determine the difference $f\left(\mathrm{C}^{\prime}=\mathrm{O}\right)-f\left(\mathrm{C}^{\prime}-\mathrm{N}\right)$. Only $\mathrm{B}_{1}$ and $\mathrm{B}_{2}$ vibrations were taken into account in the adjustment of the intrachain force constants, because only a few experimental data are available for $A$ and $B_{3}$ vibrations. Splittings between $\mathrm{A}(\nu(0,0))$ and $\mathrm{B}_{1}(\nu(0, \pi))$ frequencies and between $\mathrm{B}_{2}(\nu(\pi, 0))$ and $\mathrm{B}_{3}(\nu(\pi, \pi))$ frequencies are small for most intrachain modes, as will be shown later, and this simplified procedure does not produce any significant error. For comparison, values of the force constants based on the single-chain treatment were also derived by setting all interchain force constants equal to zero.

The values of the force constants are listed in Table V. Set I-1 corresponds to taking $f\left(\mathrm{C}^{\prime}=\mathrm{O}, \mathrm{H}--\mathrm{O}\right)=0.0$, set $\mathrm{I}-2$ to taking $f\left(\mathrm{C}^{\prime}=\mathrm{O}\right.$, $\mathrm{H}---\mathrm{O})=0.45 \mathrm{mdyn} / \AA$, and set I-3 is that for a single chain. The frequencies of crystalline PG I calculated with the force constants of set I-1 are compared with the experimental values in Table VI. Assignments based on the calculated potential energy distributions ${ }^{28}$ are also given in the table. While not a perfect description of the normal coordinate, the potential energy distribution is a useful indication of the nature of the normal vibration. The agreement between observed and calculated frequencies is generally good, except for the amide I frequencies which will be discussed in the next section. The frequencies calculated with set I-2 force constants are all within a few $\mathrm{cm}^{-1}$ of those calculated with set I-1, except for the amide $I$ modes $\left(A, 1645 ; B_{1}, 1686 ; B_{2}, 1641 ; B_{3}, 1682\right.$ ), the coupled $\mathrm{CH}_{2}$ rock and skeletal stretch $\mathrm{B}$ modes in the $\mathrm{A}$ and $\mathrm{B}_{2}$ species (A, 987 and 931, $\mathrm{B}_{2}, 987$ and 872 ), and the $\mathrm{H}---\mathrm{O}$ stretching lattice vibration $\left(B_{3}, 138\right)$. For purposes of comparison the calculated frequencies, assignments, and potential energy distributions for the single chain case (ie, using force constant set I-3) are given in Table VII.

\section{DISCUSSION}

It is of interest to compare the potential energy distributions for the normal modes of a single chain, given in Table VII, with those given by previous calculations. ${ }^{7,14,15}$ We find from the present calculation that the $\mathrm{CH}_{2}$ wagging and rocking modes make a significant contribution to the characteristic amide vibrations. This was of course not apparent in earlier calculations where the $\mathrm{CH}_{2}$ group was approximated by a point mass. The present calculation also shows that the $\mathrm{C}^{\prime}=\mathrm{O}$ out-of-plane bending mode (amide VI) and the $\mathrm{C}^{\prime}=\mathrm{O}$ in-plane bending mode (amide IV) are significantly mixed. This is of course due to the nonplanar chain 
geometry used in the present calculation as compared to the planar polypeptide chain which was assumed in the earlier calculations. The different assignments of some of the lower frequency amide modes as well as some of the skeletal modes undoubtedly arise from the different force field used in the present work as well as from the factors mentioned above.

With respect to the calculation on crystalline $P G I$, it will be seen that force constant sets I-1 and I-2 are not very different. Thus, the choice of $f\left(\mathrm{C}^{\prime}=\mathrm{O}, \mathrm{H}---\mathrm{O}\right)=0.0$ or 0.45 does not affect the other force constants appreciably. However, some force constants, such as $f\left(\mathrm{C}^{\prime} \mathrm{NC}\right), f(\mathrm{~N}-\mathrm{H}$ op), $f\left(\mathrm{C}^{\prime}-\mathrm{N}\right.$ tor $)$, and $f\left(\mathrm{~N}-\mathrm{H}\right.$ op, $\mathrm{C}^{\prime}-\mathrm{N}$ tor $)$, are considerably different for the crystal than for the single chain. This is because the amide $\mathrm{V}$ and the $\mathrm{C}^{\prime} \mathrm{NC}$ deformation vibrations are coupled with lattice vibrations of the crystal: amide $\mathrm{V}$ is coupled with the $\mathrm{N}-\mathrm{H}---\mathrm{O}$ out-of-plane bending mode and the $\mathrm{C}^{\prime} \mathrm{NC}$ vibration is coupled with the $\mathrm{H}-\cdots-\mathrm{O}$ stretching mode. This demonstrates the importance of including intermolecular interactions if a valid description of the force field and of the normal modes is to be obtained.

The agreement between observed and calculated frequencies for amide I is not very good. According to the first-order perturbation theory $29,30,31$ the frequency of an amide I mode is given by

$$
\nu\left(\delta, \delta^{\prime}\right)=\nu_{0}+\sum_{s, t} D_{s t} \cdot \cos (s \delta) \cos \left(t \delta^{\prime}\right)
$$

where $\nu_{0}$ is the unperturbed frequency and $D_{s t}$ is the constant determining interactions between peptide groups separated by $t$ chains and $s$ groups along the $t$ th neighboring chain. Usually, only $D_{\text {so's }}$ and $D_{o t}$ 's are considered to be important, and for the antiparallel chain pleated sheet only $D_{10}$ and $D_{01}{ }^{32}$ have been used so far. Thus, in this case

$$
\nu\left(\delta, \delta^{\prime}\right)=\nu_{0}+D_{10} \cos \delta+D_{01} \cos \delta^{\prime}
$$

Application of Eq. (8) to the three observed Amide I frequencies of $-\mathrm{NHCH}_{2} \mathrm{CO}-, \nu(0,0)=1674, \nu(0, \pi)=1685$, and $\nu(\pi, 0)=1636 \mathrm{~cm}^{-1}$, yields $\nu_{0}=1660.5, D_{10}=19$, and $D_{01}=-5.5 \mathrm{~cm}^{-1}$. However, we have found that the large and positive value of $D_{10}$ cannot be reproduced by using any ordinary force field, which is why there is poor agreement between the observed and calculated amide I frequencies shown in Table VI. Although calculations were also done for different repeat lengths, viz, 3.35, 3.55 , and $3.62 \AA$, for crystal structures in which neighboring chains were displaced $+0.5 \AA$ and $-0.5 \AA$ along the chain direction, with respect to the structure shown in Figure 1, a large and positive $D_{10}$ could never be obtained. Nor have we been able to reproduce the large splittings claimed by Gupta et al. ${ }^{7}$ by using their force field. It seems therefore that the only way to explain the splitting of the Amide I frequencies is to introduce direct interaction force constants between amide I vibrations, or roughly speaking, between $\mathrm{C}^{\prime}=\mathrm{O}$ stretching vibrations. 
TABLE VI

Observed and Calculated Frequencies of Crystalline Polyglycine Is (in $\mathrm{cm}^{-1}$ )

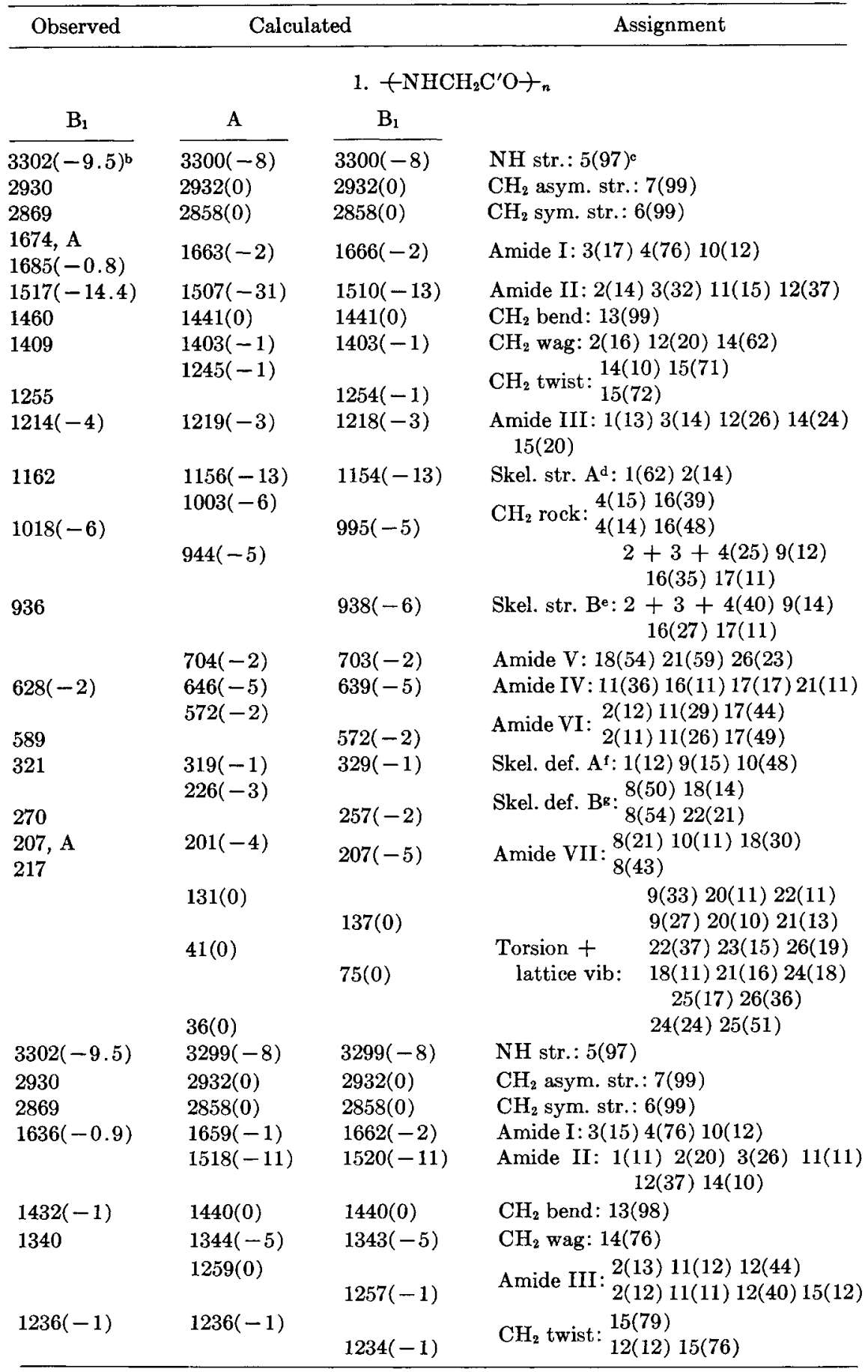


TABLE VI (continued)

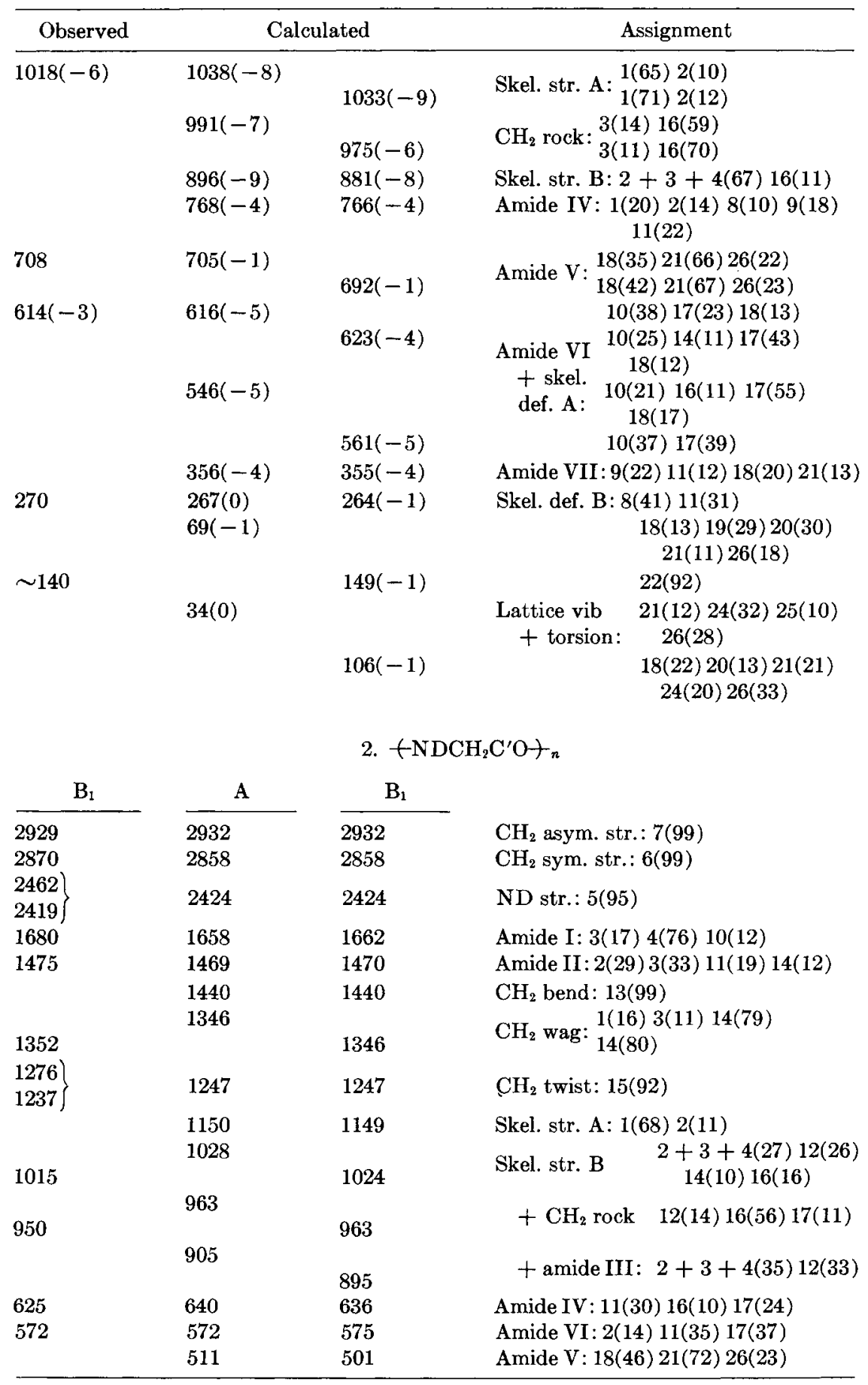


TABLE VI (continued)

\begin{tabular}{|c|c|c|c|}
\hline Observed & \multicolumn{2}{|c|}{ Calculated } & \multirow[t]{2}{*}{ Assignment } \\
\hline $\mathbf{B}_{1}$ & A & $\mathbf{B}_{1}$ & \\
\hline \multirow[b]{10}{*}{$\mathrm{B}_{2}, \mathrm{~B}_{3}$} & 316 & 326 & Skel def A. 1(13) 9(16) 10(46) \\
\hline & \multirow[t]{2}{*}{223} & & \multirow{2}{*}{ Skel. def. B: $\begin{array}{l}8(51) 18(12) \\
8(54) 22(21)\end{array}$} \\
\hline & & 255 & \\
\hline & \multirow[t]{2}{*}{197} & & Amide YII. $8(20) 18(28)$ \\
\hline & & 204 & Amae vit: $18(37) 21(11)$ \\
\hline & \multirow{3}{*}{$\begin{array}{l}129 \\
41\end{array}$} & 135 & \multirow{4}{*}{$\begin{array}{cl} & 9(28) 20(10) 21(12) \\
\text { Torsion } & 22(36) 23(15) 26(19) \\
\text { + lattice } & 18(11) 21(16) 24(18) \\
\text { vib: } & 25(17) 26(36) \\
& 24(25) 25(50)\end{array}$} \\
\hline & & & \\
\hline & & 74 & \\
\hline & \multicolumn{2}{|l|}{36} & \\
\hline & $\mathrm{B}_{2}$ & $\mathrm{~B}_{3}$ & \\
\hline 2929 & 2932 & 2932 & $\mathrm{CH}_{2}$ asym. str.: $7(99)$ \\
\hline 2870 & 2858 & 2858 & $\mathrm{CH}_{2}$ sym. str.: $6(99)$ \\
\hline $\left.\begin{array}{l}2462 \\
2419\end{array}\right\}$ & 2423 & 2423 & ND str.: $5(95)$ \\
\hline 1629 & 1653 & 1656 & \multirow{2}{*}{$\begin{array}{l}\text { Amide I: } 3(17) 4(77) 10(11) \\
\text { Amide II: } 1(11) 2(29) 3(25) 11(14) \\
\text { 13(18) }\end{array}$} \\
\hline & 1468 & 1468 & \\
\hline \multirow{2}{*}{1432} & 1433 & 1433 & $\mathrm{CH}_{2}$ bend: $13(82)$ \\
\hline & 1342 & 1341 & $\mathrm{CH}_{2}$ wag: $14(77)$ \\
\hline \multirow{2}{*}{$\left.\begin{array}{l}1276 \\
1237\end{array}\right\}$} & 1236 & 1235 & $\mathrm{CH}_{2}$ twist: $15(88)$ \\
\hline & 1035 & 1027 & Skel. str. A: $\begin{array}{l}1(49) 2(14) 16(20) \\
1(70) 2(14)\end{array}$ \\
\hline \multirow[t]{2}{*}{1015} & 1007 & 1007 & \multirow{5}{*}{$\begin{array}{cl}\mathrm{CH}_{2} \text { rock } & 1(22) 12(24) 16(25) \\
\text { + amide } & 12(39) 16(34) \\
\text { III: } & 12(45) 16(30) \\
& 12(37) 16(42) \\
\text { Skel. str. B: } \begin{array}{l}2+3+4(67) \\
2+3+4(71)\end{array} \\
\text { Amide IV: } 1(18) 2(15) 8(12) 9(16) \\
11(20)\end{array}$} \\
\hline & \multirow[t]{2}{*}{941} & & \\
\hline \multirow{3}{*}{950} & & 924 & \\
\hline & 889 & 873 & \\
\hline & 760 & 759 & \\
\hline 614 & 614 & & $10(23) 17(41)$ \\
\hline & & 616 & Amide VI $10(15) 17(58)$ \\
\hline & 542 & 553 & def. A: $\begin{array}{l}10(34) 17(35) \\
10(43) 17(27) 18(10)\end{array}$ \\
\hline 504 & 506 & & $18(68) 21(56) 26(24)$ \\
\hline & & 504 & Amide $V:{ }_{18(56) 21(65) 26(24)}$ \\
\hline & 354 & 353 & Amide VII: $9(22) 11(12) 18(15) 21(19)$ \\
\hline & 266 & 262 & Skel. def. B: 8(41) 11(31) \\
\hline & 67 & & $\begin{array}{l}18(12) 19(30) 20(30) \\
\quad 26(19)\end{array}$ \\
\hline & 34 & 148 & $\begin{array}{cl}\text { Lattice vib } & 22(92) \\
\text { + torsion: } & 21(12) 24(32) 25(10) \\
& 26(28)\end{array}$ \\
\hline & & 104 & $\begin{array}{l}18(20) 20(13) 21(19) \\
24(20) 26(34)\end{array}$ \\
\hline
\end{tabular}


TABLE VI (continued)

\begin{tabular}{|c|c|c|c|}
\hline Observed & \multicolumn{2}{|c|}{ Calculated } & Assignment \\
\hline \multicolumn{4}{|c|}{ 3. $\left(-\mathrm{NHCD}_{2} \mathrm{C}^{\prime} \mathrm{O}\right)_{n}$} \\
\hline $\mathrm{B}_{1}$ & A & $\mathbf{B}_{1}$ & \\
\hline 3297 & 3300 & 3300 & NH str.: $5(97)$ \\
\hline 2165 & 2191 & 2191 & $\mathrm{CD}_{2}$ asym. str.: $7(97)$ \\
\hline 2118 & 2096 & 2096 & $\mathrm{CD}_{2}$ sym. str.: $6(96)$ \\
\hline 1684 & 1657 & 1661 & Amide I: $3(17) 4(77)$ 10(12) \\
\hline 1498 & 1505 & 1508 & Amide II: $2(13) 3(32)$ 11(14) $12(39)$ \\
\hline 1297 & 1317 & 1315 & Amide III : $2(31)$ 12(42) $14(14)$ \\
\hline \multirow[t]{4}{*}{1189} & 1186 & 1186 & Skel. str. A: 1(71) 14(20) \\
\hline & \multirow[t]{2}{*}{1071} & & $2+3+4(20) 13(51)$ \\
\hline & & 1066 & \multirow{2}{*}{ 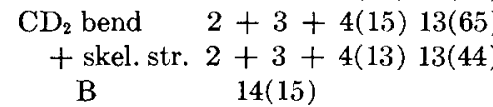 } \\
\hline & \multicolumn{2}{|l|}{1030} & \\
\hline 1015 & & 1023 & $\begin{array}{rc}+\mathrm{CD}_{2} & 2+3+4(16) 13(30) \\
\text { twist } & 14(19)\end{array}$ \\
\hline 928 & 934 & 934 & $14(13) 15(52) 17(11)$ \\
\hline \multirow[t]{3}{*}{866} & 871 & 867 & $\begin{array}{l}2+3+4(18) 14(33) \\
\quad 16(15)\end{array}$ \\
\hline & \multirow{2}{*}{$\begin{array}{l}819 \\
698\end{array}$} & 818 & $\mathrm{CD}_{2}$ rock: $15(33) 16(32) 17(16)$ \\
\hline & & 696 & Amide V: $18(52) 21(63) 26(24)$ \\
\hline \multirow[t]{2}{*}{610} & & 610 & Amide IV:2(12) 11(51) 16(13) \\
\hline & 520 & & Amide VI: $11(11) 16(26) 17(46)$ \\
\hline \multirow[t]{13}{*}{534} & & 520 & Amide $16(27) 17(46)$ \\
\hline & 300 & & (12) $9(20) 10(48)$ \\
\hline & & 314 & Ske1. de1. $\cdot 9(17) 10(51) 22(11)$ \\
\hline & 217 & & Skel def B: $8(48)$ 18(16) \\
\hline & & 244 & Dke1. de1. D. $8(55) 11(11) 22(18)$ \\
\hline & 198 & & Amide VII. $8(24) 10(10) 18(27)$ \\
\hline & & 205 & $18(42)$ \\
\hline & 122 & & $9(31) 20(12)$ \\
\hline & & 129 & $9(24) 20(11) 21(15)$ \\
\hline & 40 & & $22(36) 23(16) 25(10)$ \\
\hline & & 71 & + lattice vib.: $\begin{array}{c}26(19) \\
18(12) 21(14) 24(17)\end{array}$ \\
\hline & & 11 & $25(18) 26(33)$ \\
\hline & 35 & & $24(26) 25(49)$ \\
\hline $\mathbf{B}_{2}, \mathbf{B}_{3}$ & $\mathrm{~B}_{2}$ & $\mathbf{B}_{3}$ & \\
\hline 3297 & 3299 & 3299 & NH str.: $5(97)$ \\
\hline 2165 & 2193 & 2191 & $\mathrm{CD}_{2}$ asym. str.: $7(97)$ \\
\hline 2118 & 2095 & 2095 & $\mathrm{CD}_{2}$ sym. str.: $6(96)$ \\
\hline 1627 & 1653 & 1656 & Amide I: 3(14) 4(79) $10(12)$ \\
\hline & 1508 & 1511 & $\begin{array}{c}\text { Amide II: } 1(13) 2(18) 3(32) 11(13) \\
12(39)\end{array}$ \\
\hline & 1256 & 1253 & Amide III : 2(15) 11(11) 12(52) \\
\hline 1099 & 1107 & 1107 & $\mathrm{CD}_{2}$ wag: $2(16) 13(13) 14(\tilde{\partial} 2)$ \\
\hline 1073 & 1071 & 1070 & $\mathrm{CD}_{2}$ bend $+1(26) 13(56) 14(21)$ \\
\hline 1015 & 1016 & 1011 & skel. str. A: 1(36) 13(22) \\
\hline 928 & 937 & & $\begin{array}{l}1(12) 2+3+4(29) \\
11(12) 15(16)\end{array}$ \\
\hline
\end{tabular}


TABLE VI (continued)

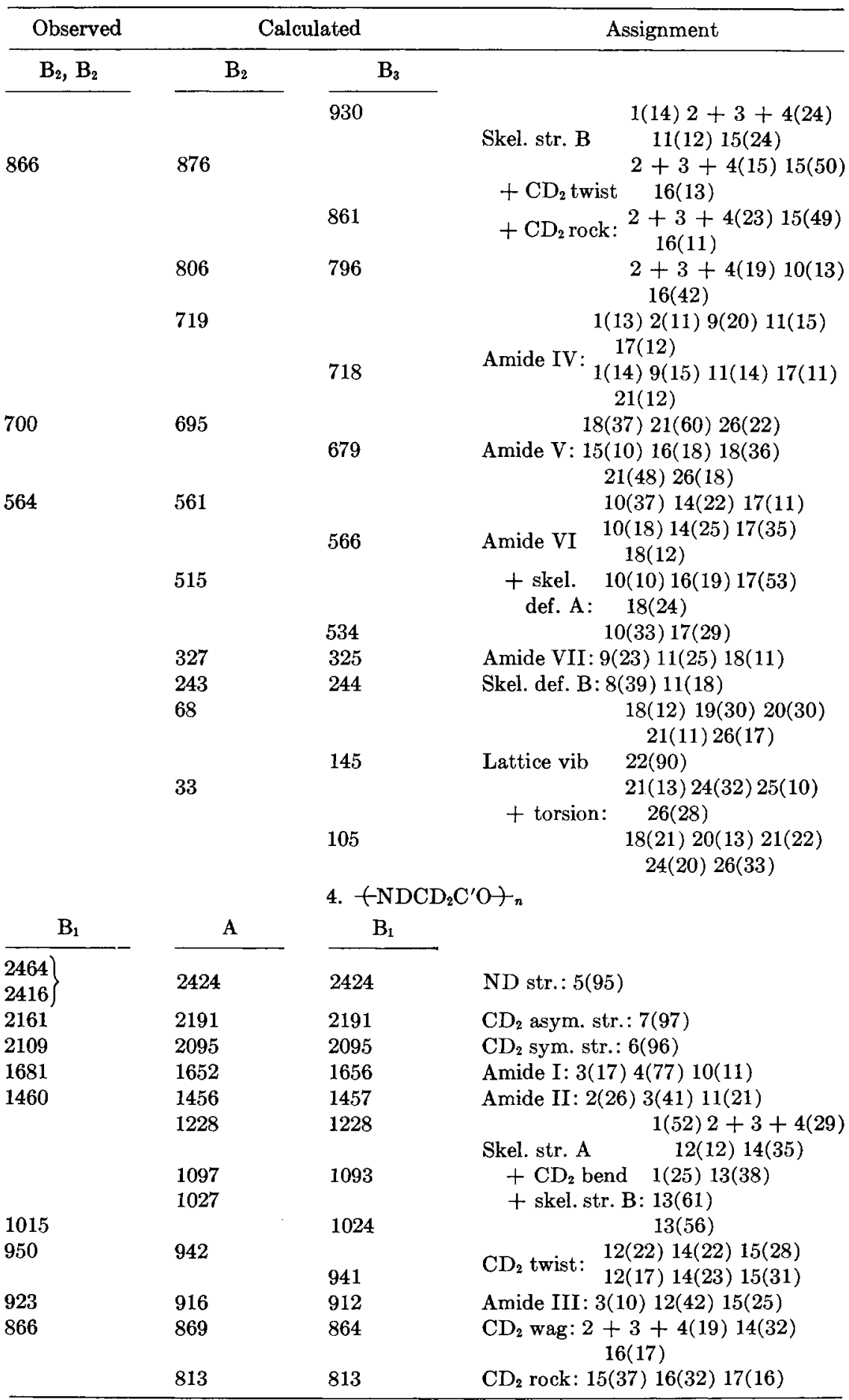


TABLE VI (continued)

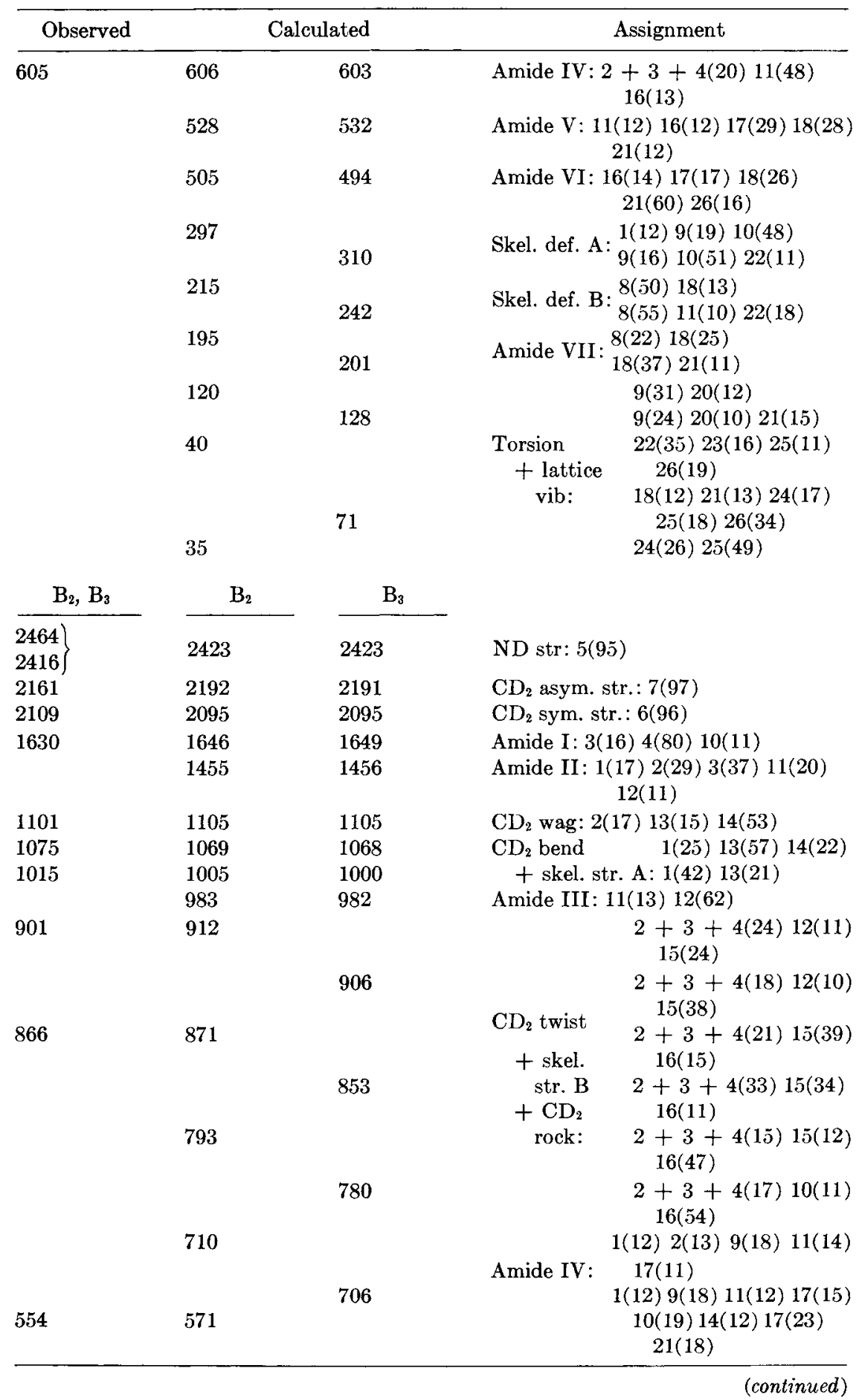


TABLE VI (continued)

\begin{tabular}{|c|c|c|c|c|}
\hline \multirow{2}{*}{$\frac{\text { Observed }}{\mathrm{B}_{2}, \mathrm{~B}_{3}}$} & \multicolumn{2}{|c|}{ Calculated } & \multicolumn{2}{|r|}{ Assignment } \\
\hline & $\mathrm{B}_{2}$ & $\mathrm{~B}_{3}$ & & \\
\hline \multirow{11}{*}{493} & & 570 & Amide VI & $10(11) 17(43) 21(11)$ \\
\hline & 515 & 529 & + skel. & $10(29) 17(25) 21(16)$ \\
\hline & 496 & & def. A: & $\begin{array}{l}10(30) 17(24) 18(24) \\
14(11) 16(11) 17(18)\end{array}$ \\
\hline & & & + amide $V$ & $: \quad 18(72) 21(36) 26(20)$ \\
\hline & & 497 & & $\begin{array}{l}10(11) 18(47) 21(58) \\
26(21)\end{array}$ \\
\hline & 325 & 322 & Amide VII : 9 & (23) $11(25) 21(12)$ \\
\hline & 243 & 244 & Skel. def. B: 8 & (39) $11(17)$ \\
\hline & 66 & & & $\begin{array}{l}18(11) 19(31) 20(30) \\
\quad 26(18)\end{array}$ \\
\hline & & 144 & Latt & $22(90)$ \\
\hline & 33 & & + torsion: & $\begin{array}{l}21(13) 24(32) 25(10) \\
\quad 26(29)\end{array}$ \\
\hline & & 104 & & $\begin{array}{l}18(20) 20(13) 21(19) \\
24(20) 26(34)\end{array}$ \\
\hline
\end{tabular}

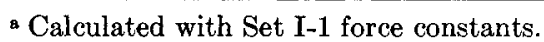

${ }^{b}()=\nu\left(\mathrm{N}^{15}\right)-\nu\left(\mathrm{N}^{14}\right)$.

c The first number refers to the symmetry coordinate in Table III ( $S_{5}$ in this case), the number in parenthesis to the fractional potential energy in this coordinate (if it is 10 or greater). Where one designation is given it signifies that both species have the same potential energy distribution.

d Skeletal stretch $\mathrm{A}$ is mainly the $\mathrm{N}-\mathrm{C}$ stretching vibration.

e Skeletal stretch $\mathrm{B}$ is mainly a symmetric stretching vibration of the $\mathrm{C}-\mathrm{C}^{\prime}-\mathrm{N}$ skeleton.

f Skeletal deformation $\mathrm{A}$ is mainly the $\mathrm{CC}^{\prime} \mathrm{N}$ deformation vibration mixed with the $\mathrm{C}^{\prime} \mathrm{NC}$ deformation.

r Skeletal deformation $\mathrm{B}$ is mainly the $\mathrm{C}^{\prime} \mathrm{NC}$ deformation vibration slightly mixed with the $\mathrm{CC}^{\prime} \mathrm{N}$ deformation.

If direct interaction force constants are introduced between $\mathrm{C}^{\prime}=0$ stretching vibrations, the one in the following structure<smiles></smiles>

that is between the groups II and IV in Figure 1, seems to be the most natural. This is because the distance between the centers of the above two $\mathrm{C}^{\prime}=\mathrm{O}$ bonds is shorter than for any other pair. This interaction corresponds to the $D_{11}$ term of Eq. (7). As we have suggested, ${ }^{33}$ the $D_{11}$ term is probably generally important in interpreting the splittings of the amide I frequencies of the antiparallel chain pleated sheet structure. Thus, we expect that a more valid approximation of Equation (7) is

$$
\nu\left(\delta, \delta^{\prime}\right)=\nu_{0}+D_{10} \cos \delta+D_{01} \cos \delta^{\prime}+D_{11} \cos \delta \cos \delta^{\prime}
$$


TABLE VII

Calculated Frequencies of Single-Chain Polyglycine Ia

\begin{tabular}{|c|c|c|}
\hline \multicolumn{2}{|c|}{ Calculated frequency } & \multirow[b]{2}{*}{ Assignment } \\
\hline$\delta=0^{\mathrm{b}}$ & $\delta=\pi$ & \\
\hline 1666 & 1660 & Amide I: $3(16) 4(74) 10(13)^{\mathrm{e}}$ \\
\hline 1508 & & Amide II: $2(13) 3(33) 11(15) 12(40)$ \\
\hline & 1519 & 1(11) 2(19) $3(27) 11(12) 12(40) 14(10)$ \\
\hline 1439 & 1439 & $\mathrm{CH}_{2}$ bend: $13(99)$ \\
\hline 1404 & 1342 & $\mathrm{CH}_{2}$ wag: $\begin{array}{l}2(16) 12(20) 14(60) \\
14(72)\end{array}$ \\
\hline 1253 & 1239 & $\mathrm{CH}_{2}$ twist: $15(80)$ \\
\hline 1218 & 1249 & Amide III: $\begin{array}{l}\begin{array}{l}1(18) 3(14) 12(29) 14(29) 15(12) \\
2(13) 11(11) 12(50)\end{array}\end{array}$ \\
\hline 1151 & 1039 & Skel. str. $A^{d}: \begin{array}{l}1(56) 2(15) \\
1(65) 2(12)\end{array}$ \\
\hline 998 & 987 & $\mathrm{CH}_{2}$ rock: $\begin{array}{l}4(18) 8(11) 16(34) \\
3(13) 8(10) 16(61)\end{array}$ \\
\hline 937 & 884 & Skel. str. Bd: $\begin{array}{l}2+3+4(22) 9(12) 16(40) 17(13) \\
2+3+4(63) 16(11)\end{array}$ \\
\hline 712 & 699 & Amide $V: \begin{array}{l}18(59) 21(55) \\
18(45) 21(68)\end{array}$ \\
\hline 639 & 778 & Amide IV: $\begin{array}{l}11(35) 16(11) 17(11) 21(16) \\
1(22) 2(18) 8(11) 9(15) 11(18)\end{array}$ \\
\hline 572 & 549 & Amide VI: $\begin{array}{l}2(12) 11(27) \quad 16(10) 17(45) \\
10(27) 16(10) \quad 17(48) 18(11)\end{array}$ \\
\hline 318 & 621 & Skel. def. $A^{d}: \begin{array}{l}1(13) 9(17) 10(45) \\
10(32) 14(11) 17(32) 18(14)\end{array}$ \\
\hline 239 & 273 & Skel. def. $B^{d}: \begin{array}{l}8(58) 10(14) \\
8(41) 11(34)\end{array}$ \\
\hline 200 & 350 & Amide VII: $\begin{array}{l}18(32) 21(18) \\
9(23) 11(11) 18(19) 21(18)\end{array}$ \\
\hline 119 & 59 & Torsion: $\begin{array}{l}9(43) 18(11) 19(10) 20(13) \\
19(50) 20(42)\end{array}$ \\
\hline
\end{tabular}

a Calculated with Set I-3 force constants.

b Modes with phase differences of 0 or $\pi$ between peptide group motions.

c Convention for potential energy distribution same as for Table VI.

d See Table VI for descriptions of modes.

If we apply Eq. (9) to the three observed amide I frequencies of PG I, and assume that $D_{10}=5 \mathrm{~cm}^{-1}$, which is the largest value given by any of our trial calculations so far, we get $\nu_{0}=1674.5, D_{01}=-19.5$, and $D_{11}=$ $14 \mathrm{~cm}^{-1}$. It should be mentioned that large splittings have also been observed for the $\mathrm{C}=\mathrm{O}$ stretching frequencies of dimers of carboxylic acids ${ }^{34}$ which have the structure<smiles></smiles>

and the existence of some sort of direct interaction between the $\mathrm{C}=\mathrm{O}$ stretching vibrations was also suggested in this case. ${ }^{35}$ In the latter case 
the interaction term corresponding to $D_{11}$ was found to be -20 to -40 $\mathrm{cm}^{-1}$.

The $D_{11}$ term could have its physical origin in the interactions between the transition dipoles of the $\mathrm{C}=\mathrm{O}$ stretching vibrations, which would be given by

$$
f\left(\mathrm{C}==\mathrm{O}_{1}, \mathrm{C}=\mathrm{O}_{2}\right)=0.1 \times\left(\frac{\partial \mu^{2}}{\partial r_{\mathrm{C}=\mathrm{o}}}\right)^{2} \cdot \frac{\cos \alpha-3 \cos \beta \cdot \cos \gamma}{|\mathbf{R}|^{3}}
$$

where $f\left(\mathrm{C}=\mathrm{O}_{1}, \mathrm{C}=\mathrm{O}_{2}\right)$ is the interaction force constant between the two $\mathrm{C}=\mathrm{O}$ stretching vibrations, $\mathbf{R}$ is the vector connecting the centers of $\boldsymbol{\mu}_{1}$ and $\boldsymbol{u}_{2}, \cos \alpha=\boldsymbol{\mu}_{1} \cdot \boldsymbol{u}_{2} /\left|\boldsymbol{u}_{1}\right|\left|\boldsymbol{u}_{2}\right|, \cos \beta=\boldsymbol{u}_{1} \cdot \mathbf{R} /\left|\boldsymbol{\mu}_{1}\right||\mathbf{R}|$, and $\cos \gamma=\boldsymbol{u}_{2} \cdot \mathbf{R} /$ $\left|\mathbf{u}_{2}\right||\mathbf{R}|, \boldsymbol{u}_{1}$ and $\mathbf{u}_{2}$ being the two transition dipoles $\left(\left|\mathbf{u}_{2}\right|=\left|\mathbf{u}_{2}\right|=\left|\left(\partial_{\mu} / \partial r_{\mathrm{C}=0}\right)\right|\right)$. $|\mathbf{R}|$ is gjven in $\AA,\left(\partial \mu / \partial r_{\mathrm{C}=0}\right)$ in Debye $/ \AA$, and $f\left(\mathrm{C}=\mathrm{O}_{1}, \mathrm{C}=\mathrm{O}_{2}\right)$ in mdyn/ $/$. If we assume that the center of the transition dipole of the amide I vibration is on the $\mathrm{C}^{\prime}=\mathrm{O}$ bond located $0.6 \AA$ from the $\mathrm{C}^{\prime}$ atom, that the dipole is tilted by $20^{\circ}$ from the $\mathrm{C}^{\prime}=\mathrm{O}$ bond toward the $\mathrm{N} \rightarrow \mathrm{C}$ direction, ${ }^{36}$ and that $\left(\partial \mu / \partial r_{\mathrm{C}=0}\right)=8 \mathrm{D} / \AA$, we get

$$
\begin{gathered}
f\left(\mathrm{C}^{\prime}=\mathrm{O}_{\mathrm{I}}, \mathrm{C}^{\prime}=\mathrm{O}_{\mathrm{II}}\right)=f\left(\mathrm{C}^{\prime}=\mathrm{O}, \mathrm{C}^{\prime}=\mathrm{O}\right)_{10}=-0.03 \\
f\left(\mathrm{C}^{\prime}=\mathrm{O}_{\mathrm{II}}, \mathrm{C}^{\prime}=\mathrm{O}_{\mathrm{III}}\right)=f\left(\mathrm{C}^{\prime}=\mathrm{O}, \mathrm{C}^{\prime}=\mathrm{O}\right)_{01}=-0.12 \\
f\left(\mathrm{C}^{\prime}=\mathrm{O}_{\mathrm{II}}, \mathrm{C}^{\prime}=\mathrm{O}_{\mathrm{IV}}\right)=f\left(\mathrm{C}^{\prime}=\mathrm{O}, \mathrm{C}^{\prime}=\mathrm{O}\right)_{11}=0.26
\end{gathered}
$$

where I, II, III and IV denote the four groups shown in Figure 1 and 10, 01, and 11 correspond to the subscripts in Eq. (9). Readjusting the force constants $f\left(\mathrm{C}^{\prime}=\mathrm{O}\right)$ and $f\left(\mathrm{C}^{\prime}=\mathrm{O}, \mathrm{H}---\mathrm{O}\right)$ to 9.71 and $0.35 \mathrm{md} / \mathrm{A}$, respectively, we calculate the four amide I frequencies of $\mathrm{PG} I$ at $\nu(0,0)=1674$, $\nu(0, \pi)=1688, \nu(\pi, 0)=1639$, and $\nu(\pi, \pi)=1721 \mathrm{~cm}^{-1}$, in good agreement with experiment. It should be noted that the application of Eq. (10) to dimers of carboxylic acids always yields negative interaction terms (of magnitude -15 to $-30 \mathrm{~cm}^{-1}$ ), as found by experiment. The direct interaction between $\mathrm{C}^{\prime}=\mathrm{O}$ transition dipoles thus seems to be a reasonable and probably necessary mechanism for accounting for the Amide I splittings in polypeptides and proteins.

We thank Dr. T. Miyazawa of Osaka University and Dr. K. Fukushima of Shizuoka University for supplying us with the details of their calculations. This work was supported by grants GP-10922 and GB-15682 from the National Science Foundation. A postdoctoral fellowship from the Macromolecular Research Center at the University of Michigan to one of us (Y.A.) is gratefully acknowledged.

\section{References}

1. A. Elliott and B. R. Malcolm, Trans. Faraday Soc., 52, 528 (1956).

2. T. Miyazawa, Bull. Chem. Soc. Japan, 34,691 (1961).

3. S. Suzuki, Y. Iwashita, T. Shimanouchi, and M. Tsuboi, Biopolymers, 4, 337 (1966).

4. S. Krimm and K. Kuroiwa, Biopolymers, 6,401 (1968).

5. M. Smith, A. G. Walton, and J. L. Koenig, Biopolymers, 8, 29 (1969).

6. E. W. Small, B. Fanconi, and W. L. Peticolas, J. Chem. Phys., 52, 4369 (1970). 
7. V. D. Gupta, S. Trevino, and H. Boutin, J. Chem. Phys., 48, 3008 (1968).

8. R. D. Singh and V. D. Gupta, Spectrochim. Acta, 27A, 385 (1971).

9. E. R. Blout and S. G. Linsley, J. Am. Chem. Soc., 74, 1946 (1952).

10. Y. Koyama and T. Shimanouchi, Biopolymers, 6, 1037 (1968).

11. M. Avignon and C. Garrigou-Lagrange, Spectrochim. Acta, 27A, 297 (1971).

12. J. Jakeš and S. Krimm, Spectrochim. Acta, 27A, 19 (1971).

13. J. Jakeš and S. Krimm, Spectrochim. Acta, 27A, 35 (1971).

14. K. Fukushima, Y. Ideguchi, and T. Miyazawa, Bull. Chem. Soc. Japan, 36, 1301 (1963).

15. T. Miyazawa, in Poly- $\alpha$-Amino Acids, G. D. Fasman, Ed., Marcel Dekker, Inc., New York, 1967.

16. K. Fukushima and T. Miyazawa, Paper, Ann. Meet. Chem. Soc. Japan, Osaka, April, 1965; cited as Ref. 25 in 15.

17. E. B. Wilson, Jr., J. C. Decius, and P. C. Cross, Molecular Vibrations, MeGraw-Hill Co., New York, 1955.

18. T. Shimanouchi, M. Tsuboi, and T. Miyazawa, J. Chem. Phys., 35, 1597 (1961);

T. Miyazawa, Y. Ideguchi, and K. Fukushima, J. Chem. Phys., 38, 2709 (1963); H. Sugeta and T. Miyazawa, J. Chem. Phys., 47, 2034 (1967).

19. W. J. Astbury, Nature, 163, 722 (1949).

20. C. H. Bamford, L. Brown, E. M. Cant, A. Elliott, W. E. Hanby, and B. R. Malcolm, Nature, 176, 396 (1955).

21. V. Sasisekharan, in Collagen. G. N. Ramachandran, Ed., Interscience, New York, 1962.

22. As mentioned in the text, $\mathrm{N}-\mathrm{H}---\mathrm{O}$ and $\mathrm{C}=\mathrm{O}---\mathrm{H}$ are very nearly linear. Accordingly, the pair of bending coordinates for a linear, triatomic group were adopted for them.

23. M. Tasumi, T. Shimanouchi, and T. Miyazawa, J. Mol. Spectroscopy, 11, 422 (1963).

24. S. Krimm and K. Kuroiwa, Abstract J-183, Seventh International Congress of Biochemistry, Tokyo, 1967.

25. K. Itoh, T. Shimanouchi, and M. Oya, Biopolymers, 7, 649 (1969).

26. K. Itoh and T. Shimanouchi, Biopolymers, 5, 921 (1967).

27. J. H. Schachtschneider and R. G. Snyder, Spectrochim. Acta, 19, 117 (1963).

28. Y. Morino and K. Kuchitsu, J. Chem. Phys., 20, 1809 (1952).

29. T. Miyazawa, J. Chem. Phys., 32, 1647 (1960).

30. T. Miyazawa and E. R. Blout, J. Am. Chem. Soc.; 83, 712 (1961).

31. S. Krimm, J. Mol. Biol., 4, 528 (1962).

32. $D_{10}$ and $D_{01}$ correspond to $D_{1}$ and $D_{1}{ }^{\prime}$, respectively, which are commonly used.

33. S. Krimm and Y. Abe, Proc. Nat. Acad. Sci., in press.

34. S. Kishida and K. Nakamoto, J. Chem. Phys., 41, 1558 (1964), and references cited therein.

35. M. Suzuki and T. Shimanouchi, J. Mol. Spectroscopy, 29,415 (1969).

36. I. Sandeman, Proc. Royal. Soc. (London), A232, 105 (1955).

Received March 18, 1972 